\title{
Recent advances in crystalline hydrated borates with non-metal or transition-metal complex cations
}

Beckett, Michael

\section{Coordination Chemistry Reviews}

DOI:

10.1016/j.ccr.2015.12.012

Published: 15/09/2016

Peer reviewed version

Cyswllt i'r cyhoeddiad / Link to publication

Dyfyniad o'r fersiwn a gyhoeddwyd / Citation for published version (APA):

Beckett, M. (2016). Recent advances in crystalline hydrated borates with non-metal or transitionmetal complex cations. Coordination Chemistry Reviews, 323, 2-14.

https://doi.org/10.1016/j.ccr.2015.12.012

\footnotetext{
Hawliau Cyffredinol / General rights

Copyright and moral rights for the publications made accessible in the public portal are retained by the authors and/or other copyright owners and it is a condition of accessing publications that users recognise and abide by the legal requirements associated with these rights.

- Users may download and print one copy of any publication from the public portal for the purpose of private study or research.

- You may not further distribute the material or use it for any profit-making activity or commercial gain

- You may freely distribute the URL identifying the publication in the public portal ?
}

Take down policy

If you believe that this document breaches copyright please contact us providing details, and we will remove access to the work immediately and investigate your claim. 


\title{
Recent advances in crystalline hydrated borates with non-metal or transition-metal complex cations
}

\author{
Michael A. Beckett* \\ School of Chemistry, Bangor University, Bangor, Gwynedd, LL57 2UW, UK \\ *m.a.beckett@bangor.ac.uk
}

\begin{abstract}
Structural aspects of crystalline hydrated polyborate salts containing polyborate anions partnered with either cationic transition-metal complexes or non-metal (organic) cations are documented. The structures are described in terms of Christ and Clark's and Burns' descriptors. The review, which concentrates on the period 2000-2015, also describes synthetic approaches (hydrothermal, solvothermal, flux methods) and physical and spectroscopic properties of the polyborate salts.
\end{abstract}

Keywords: Hydrated borates; Non-metal cations; Polyborate anions; Transition-metal complex cations; XRD.

\subsection{Introduction and scope of review}

Anions containing boron exclusively bound to oxygen are generally referred to as borates. The term borate is used in this review although oxidoborates is a preferred named by IUPAC. There are more 
than two hundred minerals containing boron and these naturally occurring compounds, together with many known synthetic examples, represent an important and a significant proportion of the chemistry of boron. The structures of borates are generally complex, but can be summarized as anionic entities containing trigonal $\mathrm{BO}_{3}$ and tetrahedral $\left[\mathrm{BO}_{4}\right]^{-}$units linked together by the sharing of oxygen atoms, partnered by suitable cations. The resulting anionic entities may result in isolated chains, rings, or cages, or may condense further to form polymeric chains, sheets or three-dimensional networks. The non-shared oxygen atoms will either carry a further negative charge (anhydrous borates) or will be protonated (hydrated borates). Hydrated borates are often further hydrated by waters of crystallization. Thus 'borax', $\mathrm{Na}_{2}\left[\mathrm{~B}_{4} \mathrm{O}_{5}(\mathrm{OH})_{4}\right] \cdot 8 \mathrm{H}_{2} \mathrm{O}$, is a hydrated tetraborate formed by the formal condensation of two $\mathrm{B}(\mathrm{OH})_{3}$ and two $\left[\mathrm{B}(\mathrm{OH})_{4}\right]^{-}$units generating a dianion (see Fig 4a) with five oxygen atom bridges (oxo bridges) and eight waters of crystallization. The anion is also classified as an 'isolated' hydrated anion since it is a discrete, rather than polymeric, anionic entity. Boroxole $\left(\mathrm{B}_{3} \mathrm{O}_{3}\right)$ rings are a common structural feature of polyborate chemistry and the $\left[\mathrm{B}_{4} \mathrm{O}_{5}(\mathrm{OH})_{4}\right]^{2-}$ anion is comprised of two fused boroxole $\left(\mathrm{B}_{3} \mathrm{O}_{3}\right)$ rings with two boron atoms and one oxygen atom in common. This review focusses on synthesis, properties and structural studies of crystalline hydrated borates with either non-metal (organic) or transition-metal coordination complexes as cations. A more detailed explanation of how polyborates may be classified is described in Section 2. Anhydrous polyborates, containing the $\mathrm{B}-\mathrm{O}^{-}$motif, and polyborates with $\mathrm{M}-\mathrm{O}-\mathrm{B}$ bonds are outside the scope of this review. The review focuses on the literature since 2000. Abbreviations are given in Table 1, or in the text when necessary.

\subsection{Reviews and background}

There are many detailed and thorough accounts on structural aspects of boron-oxygen chemistry. Many of the earlier reviews containing useful structural information include those by Farmer (1982) [1], who reviewed metal borates, and Heller (1986) [2] who surveyed structural aspects of borates and polyborates; both of these reviews focussed primarily on synthetic and naturally occurring metal borates. Becker (1998) [3] reviewed the role of borate materials in non-linear optics and focussed on 
synthetic metal borates. Earlier, Christ and Clark (1977) [4] had described a convenient system for classifying polyborate anions. They describe polyborate anions in terms of combinations of defined Fundamental Building Blocks (FBB) with $n$ boron atoms (Figure 1). Each boron may be three- or four-coordinate, and this is also specified in the descriptor following the colon. Thus $\mathrm{K}\left[\mathrm{B}_{3} \mathrm{O}_{3}(\mathrm{OH})_{4}\right] \cdot 2 \mathrm{H}_{2} \mathrm{O}$ (Figure 3a) $(\mathrm{FBB}=3)$ with two trigonal boron centres and one tetrahedral centre is represented as $3: 2 \Delta+\mathrm{T}$, where $\Delta$ and $\mathrm{T}$ represent trigonal and tetrahedral centres, respectively. Polymeric systems are differentiated by adding $\infty_{\mathrm{y}}$ for chains $(\mathrm{y}=1)$ sheets $(\mathrm{y}=2)$ or networks $(\mathrm{y}=$ 3). Burns and co-workers $(1995,1999)$ [5-7] modified Christ and Clark's approach so as to differentiate, within the classification descriptor, between possible topological FBB isomers by focussing on boroxole $\left(\mathrm{B}_{3} \mathrm{O}_{3}\right)$ rings and how they are linked together. These systems are generally accepted and both are used throughout this manuscript. The Burns' descriptor for $\mathrm{K}\left[\mathrm{B}_{3} \mathrm{O}_{3}(\mathrm{OH})_{4}\right] \cdot 2 \mathrm{H}_{2} \mathrm{O}$ is $2 \Delta \square:<2 \Delta \square>$ with the coordination numbers for boron atoms within each boroxole ring are enclosed within $<>$.

In more recent years there have been numerous publications describing structural aspects and properties of synthetic polyborate species. Hawthorne (2001) [8] described a bond-valence approach to the structure, chemistry and paragenesis of hydroxyl-hydrated oxysalt minerals. Touboul (2003) [9] surveyed the crystal chemistry of five families of alkaline or pseudo-alkaline hydrated borates and the processes that occur during their thermal dehydration to anhydrous borates. Schubert, in 2003 [10] and 2009 [11], reviewed synthetic and structural aspects of non-metal borates, and has surveyed (2003) [12] the industrial uses of borate materials. Belokoneva (2005) [13] has undertaken a detailed analysis of metal borate crystal chemistry using the extended Dornberger-Schiff orderdisorder theory based on the recognition of building blocks of various dimensions. More recently Schubert (2011) [14] published an encyclopedic article on boron oxides, boric acid and borates containing much useful information. 
<smiles>[B]1OBOBO1</smiles>

$n=3$<smiles>S=[AsH]</smiles><smiles>[B]1OBO[B-]2(O1)OBOBO2</smiles>

$n=7$<smiles>O[B-]12OBO[B-](O)(OBO1)O2</smiles>

$n=4(4-1)$<smiles>O[B-]12OBO[B-](O)(O)[B-](O)(OBO1)OBO2</smiles>

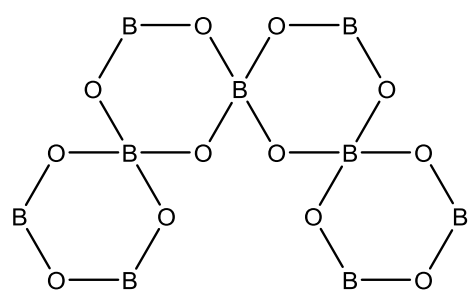

$n=9$

Figure 1. Fundamental Building Blocks (FBB) in polyborate chemistry used within this review. The heptaborate FBB was not included in Christ and Clark's original publication [4], which lists two topologically distinct tetraborate FBBs, named 4-1 and 4-2.

\subsection{XRD structural studies}

\subsection{Monoborates}

It is well-known that $\mathrm{B}(\mathrm{OH})_{3}$ functions primarily as a Lewis acid in aqueous solution and coordinates $\mathrm{H}_{2} \mathrm{O}$ [15]. The resulting adduct is responsible for the Bronsted acidity of boric acid in aqueous solution by subsequent deprotonation and formation of the tetrahedral monoborate anion, $\left[\mathrm{B}(\mathrm{OH})_{4}\right]^{-}$. The compound $\left[\mathrm{NMe}_{4}\right]\left[\mathrm{BO}(\mathrm{OH})_{2}\right]$, which contains the elusive $\left[\mathrm{BO}(\mathrm{OH})_{2}\right]^{-}$anion (Figure 2), has been obtained as a part of a urea inclusion complex in $\left[\mathrm{NMe}_{4}\right]\left[\mathrm{BO}(\mathrm{OH})_{2}\right] \cdot 2\left(\mathrm{NH}_{2}\right)_{2} \mathrm{CO} \cdot \mathrm{H}_{2} \mathrm{O}$ [16]. The anion forms a zig-zag H-bonded ribbon of monoborate anions and the unique oxygen atom also has the 
water molecule $\mathrm{H}$-bonded to it. One of the B-O distances, 1.323(5) $\AA$, is significantly shorter than the other two distances, (1.395(3) $\mathrm{A})$, indicating that the resonance with $\mathrm{B}=\mathrm{O}$ plays an important contribution to the electronic structure.<smiles>O=[PH](O)O</smiles>

Figure 2. The monoborate anion $\left[\mathrm{BO}(\mathrm{OH})_{2}\right]^{-}$as is observed

in the inclusion complex $\left[\mathrm{NMe}_{4}\right]\left[\mathrm{BO}(\mathrm{OH})_{2}\right] 2\left(\mathrm{NH}_{2}\right)_{2} \mathrm{CO} \cdot \mathrm{H}_{2} \mathrm{O}[16]$.

\subsection{Triborates}

Compounds containing the isolated triborate(1-) anion (Figure 3a) are relatively rare but there have been three reports of this class of compound since 2000. The salts reported are $\left[\mathrm{HOCH}_{2} \mathrm{CMe}_{2} \mathrm{NH}_{3}\right]\left[\mathrm{B}_{3} \mathrm{O}_{3}(\mathrm{OH})_{4}\right]$ [17], $\left[\mathrm{H}_{2} \mathrm{~N}\left(\mathrm{CH}_{2} \mathrm{CH}_{2}\right)_{2} \mathrm{NH}_{2}\right]\left[\mathrm{B}_{3} \mathrm{O}_{3}(\mathrm{OH})_{4}\right]$ [18] and $[\mathrm{Co}(\text { diNOsar })]_{2}\left[\mathrm{~B}_{3} \mathrm{O}_{3}(\mathrm{OH})_{4}\right] 5 \mathrm{Cl} \cdot 4.75 \mathrm{H}_{2} \mathrm{O}($ diNOsar $=$ 1,8-dinitro-3,6,10,13,16,19-hexaazabicyclo(6.6.6)icosane) [19]. A neutral triborate $\mathrm{B}_{3} \mathrm{O}_{4}(\mathrm{OH}) \cdot 1 / 2$ pip (pip = piperazine) (Figure 3b), which contains a condensed one-dimensional helical borate chain, is the first organic-inorganic hybrid borate reported [20]. This zwitterionic neutral compound has each piperazine coordinated/bridging two triborate(1-) moieties, forming alternating piperazine/borate sheets. The industrially important zinc borate, $\mathrm{Zn}\left[\mathrm{B}_{3} \mathrm{O}_{4}(\mathrm{OH})_{3}\right]$, has also been structurally characterized [21]. It has a partially condensed structure with an infinite poly(triborate)(2-) chain and additional Zn-O interactions. The $\left[\left\{\mathrm{B}_{3} \mathrm{O}_{4}(\mathrm{OH})_{3}\right\}_{\mathrm{n}}\right]^{2 \mathrm{n}-}$ anion is illustrated in Figure $3 \mathrm{c}$ and can be classified as $3: \infty_{1}(\Delta+2 \mathrm{~T})$ or $\Delta 2 \square:<\Delta 2 \square>$. A compound described as a novel potassium triborate contains the isolated dodecaborate(4-) anion and is described in Section 3.9 [22]. 
<smiles>OB1OB(O)O[B-](O)(O)O1</smiles>

(a)

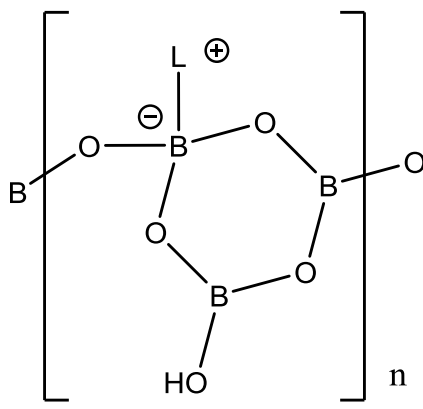

(b)

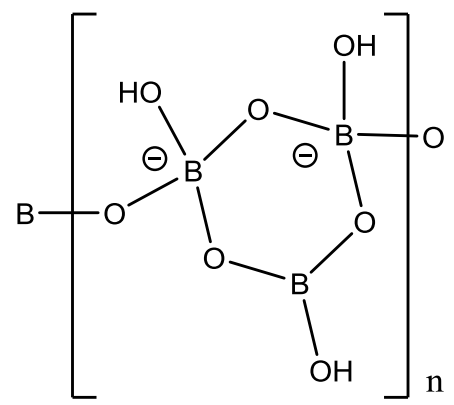

(c)

Figure 3. (a) Isolated triborate(1-) anion as found in $\mathrm{K}\left[\mathrm{B}_{3} \mathrm{O}_{3}(\mathrm{OH})_{4}\right] \cdot 2 \mathrm{H}_{2} \mathrm{O}[114]$, and poly(triborate)(2-) anions as found in (b) $\mathrm{B}_{3} \mathrm{O}_{4}(\mathrm{OH}) \cdot 1 / 2$ (pip) [20], and (c) $\mathrm{Zn}\left[\mathrm{B}_{3} \mathrm{O}_{4}(\mathrm{OH})_{3}\right]$ [21].

\subsection{Tetraborates}

The isolated tetraborate(2-) anion shown in Figure 4a has the structural descriptors of 4-1:2 $\Delta+2 \mathrm{~T}$ or $2 \Delta 2 \square:\langle\Delta 2 \square>=<\Delta 2 \square>$. Two salts containing this anion partnered with non-metal cations have been reported: the cyclohexane-1,4-diammonium salt $\left[\mathrm{C}_{6} \mathrm{H}_{10}\left(\mathrm{NH}_{3}\right)_{2}\right]\left[\mathrm{B}_{4} \mathrm{O}_{5}(\mathrm{OH})_{4}\right] \cdot 2.5 \mathrm{H}_{2} \mathrm{O}[23,24]$ and the 1,2-ethylenediammonium salt $\left[\mathrm{H}_{2} \mathrm{en}_{2}\left[\mathrm{~B}_{4} \mathrm{O}_{5}(\mathrm{OH})_{4}\right]\left[\mathrm{B}_{7} \mathrm{O}_{9}(\mathrm{OH})_{5}\right] \cdot 3 \mathrm{H}_{2} \mathrm{O}\right.$ [25]. The latter is a unique example of a non-metal cation double salt containing two isolated polyborate anions. There are three examples of transition-metal cation salts templating this anion: $\left[\mathrm{Co}(\mathrm{en})_{3}\right]\left[\mathrm{B}_{4} \mathrm{O}_{5}(\mathrm{OH})_{4}\right] \mathrm{Cl}_{3} 3 \mathrm{H}_{2} \mathrm{O}[26]$, $\left[\mathrm{NH}_{4}\right]\left[\mathrm{Co}\left(\mathrm{NH}_{3}\right)_{5}\left(\mathrm{H}_{2} \mathrm{O}\right)\right]\left[\mathrm{B}_{4} \mathrm{O}_{5}(\mathrm{OH})_{4}\right] \cdot 6 \mathrm{H}_{2} \mathrm{O}[27]$, and $\left[\mathrm{Cu}(\mathrm{en})_{2}\left\{\mathrm{~B}(\mathrm{OH})_{3}\right\}\right]\left[\mathrm{B}_{4} \mathrm{O}_{5}(\mathrm{OH})_{4}\right] \cdot \mathrm{B}(\mathrm{OH})_{3}[28]$. The structure of the latter salt is complex with the $\left[\mathrm{Cu}(\mathrm{en})_{2}\right]^{2+}$ cation becoming octahedral with a coordinated monodentate $\mathrm{B}(\mathrm{OH})_{3}$ ligand trans to a coordinated tetraborate(2-) (through the hydroxyl group on a trigonal boron centre) with the salt having an additional boric acid spacer unit $\mathrm{H}$-bonded to the tetraborate(2-) anion. The structure of borax, $\mathrm{Na}_{2}\left[\mathrm{~B}_{4} \mathrm{O}_{5}(\mathrm{OH})_{4}\right] \cdot 8 \mathrm{H}_{2} \mathrm{O}$, has been re-determined by XRD at $145 \mathrm{~K}$ [29a] and the O-H distances were found to be shorter by an average of 0.127(19) $\AA$ than those obtained at $296.5 \mathrm{~K}$ in a previous neutron diffraction study [29b]. A condensed polymeric tetraborate(2-) anion chain, $\left[\left\{\mathrm{B}_{4} \mathrm{O}_{6}(\mathrm{OH})_{2}\right\}_{\mathrm{n}}\right]^{2 \mathrm{n}-}$ (Figure $\left.4 \mathrm{~b}\right)$, is present in $\left[\mathrm{Zn}(\mathrm{dab})_{0.5}(\mathrm{dab})_{0.5}\left(\mathrm{~B}_{4} \mathrm{O}_{6}(\mathrm{OH})_{2}\right)\right] \cdot \mathrm{H}_{2} \mathrm{O}$ (dab = 1,4-diaminobutane) [30]. The anion can be classified as 
4-1: $\infty_{1}(2 \Delta+2 \mathrm{~T})$ or $2 \Delta 2 \square:<\Delta 2 \square>=<\Delta 2 \square>$ and functions as a bridging ligand to two $\mathrm{Zn}$ centres via two oxo bridges, creating an organic-inorganic hybrid zinc borate.

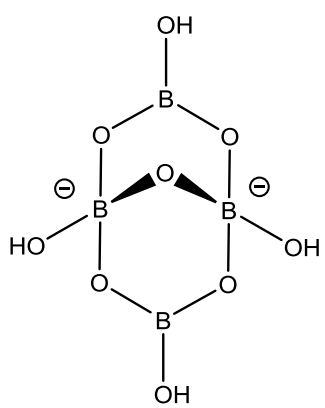

(a)

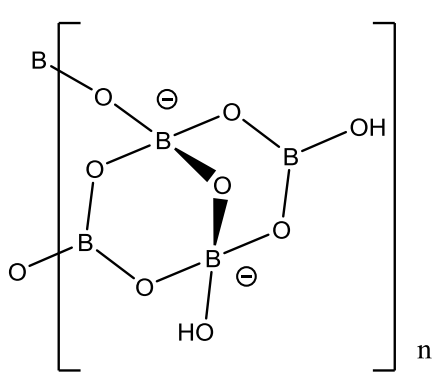

(b)

Figure 4. (a) Isolated tetraborate(2-) anion as found in borax, $\mathrm{Na}_{2}\left[\mathrm{~B}_{4} \mathrm{O}_{5}(\mathrm{OH})_{4}\right] 8 \mathrm{H}_{2} \mathrm{O}[29]$, (b) $\left[\left\{\mathrm{B}_{4} \mathrm{O}_{6}(\mathrm{OH})_{2}\right\}_{\mathrm{n}}\right]^{2 \mathrm{n}-}$ as found in the organic-inorganic hybrid $\left[\mathrm{Zn}(\mathrm{dab})_{0.5}\left(\mathrm{dab}^{\prime}\right)_{0.5}\left(\mathrm{~B}_{4} \mathrm{O}_{6}(\mathrm{OH})_{2}\right)\right] \cdot \mathrm{H}_{2} \mathrm{O}[30]$.

\subsection{Pentaborates}

The isolated pentaborate(1-) anion (Figure 5a) has the structural descriptors $5: 4 \Delta+\mathrm{T}$ or $4 \Delta 1 \square:<2 \Delta \square>-$ $\langle 2 \Delta \square\rangle$. Salts containing this anion are easily prepared and this class of compound is found in the majority of structurally characterized polyborates since 2000 . These compounds are reported in Table 1, where they are subdivided into whether the cation is derived from organic bases (NMC, non-metal cation) $[18,31-59,75,115]$, transition-metal complexes [26,50,60-73], or s-block elements [31,74]. For convenience $\left[\mathrm{B}_{5} \mathrm{O}_{6}(\mathrm{OH})_{4}\right]^{-}$(Figure 5a) is denoted as 5 Table 1 . 
<smiles>OB1OB(O)O[B-]2(O1)OB(O)OB(O)O2</smiles>

(a)

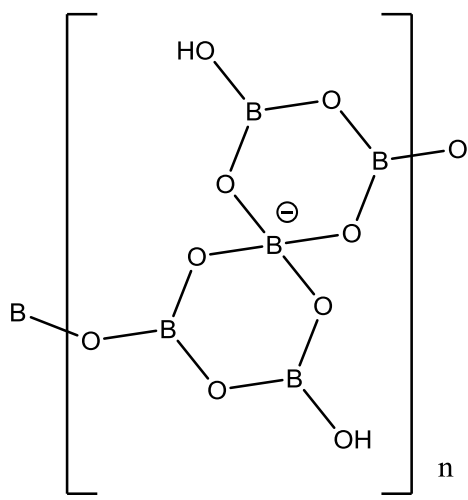

(b)

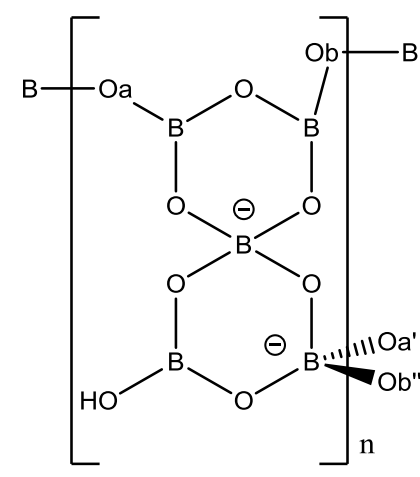

(c)

Figure 5. (a) Isolated pentaborate(1-) anion as found in $\left[\mathrm{NH}_{4}\right]\left[\mathrm{B}_{5} \mathrm{O}_{6}(\mathrm{OH})_{4}\right] \cdot 2 \mathrm{H}_{2} \mathrm{O}[31]$ and

poly(pentaborate)(2-) ions as found in (b) $\left[\mathrm{Ag}(\mathrm{py})_{2}\right]\left[\mathrm{B}_{5} \mathrm{O}_{7}(\mathrm{OH})_{2}\right][79]$ and (c) $\left[\mathrm{H}_{3} \mathrm{NCH}_{2} \mathrm{CH}_{2} \mathrm{NH}_{3}\right]\left[\mathrm{B}_{5} \mathrm{O}_{8}(\mathrm{OH})\right]$ [80].

The solid-state structures of all isolated pentaborate(1-) salts, and other isolated polyborate anions, contain extensive anion-anion H-bond interactions. The spiro boron centre of the pentaborate(1-) anion, ensures that the planar boroxole rings within the pentaborate(1-) anion are perpendicular to one another, and this facilitates the formation of a three-dimensional rather than a two-dimensional (layered) anionic lattice, via H-bonds. Four common H-bonding motifs have been observed between neighbouring pentaborate(1-) anions (Figure 6) and these are differentiated, using Etter nomenclature [86] and by labelling of the H-bond acceptor sites $(\alpha, \beta$, or $\gamma)$ as described by Schubert [40]. These H-bond interactions have been calculated (DFT) to be $-21 \mathrm{~kJ} \mathrm{~mol}^{-1}\left(\mathrm{R}_{2}{ }^{2}(8)\right.$, reciprocal- $\alpha),-16 \mathrm{~kJ} \mathrm{~mol}^{-1}\left(\mathrm{R}_{2}^{2}(12)\right.$, reciprocal- $\left.\beta\right),-16 \mathrm{~kJ} \mathrm{~mol}^{-1}\left(\mathrm{R}_{2}^{2}(8)\right.$, reciprocal- $\left.\gamma\right)$, and $-10 \mathrm{~kJ} \mathrm{~mol}^{-1}$ $(\mathrm{C}(8), \beta$-chain), and the reciprocal- $\alpha$ interaction is particularly strong [45]. Each pentaborate(1-) anion forms four H-bonds to four neighbours and a variety of configurations are possible. Some configurations occur frequently and yet many configurations are unique to particular compounds. However, the $\alpha, \alpha, \alpha, \beta$ acceptor site configuration is particularly common and two variants of this configuration, both with $C(8) \beta$-interactions, have been described $[43,76,77]$. These structures are 
referred to as 'herringbone' [35,36,38-41,43,48,57] or 'brickwall' [37,41,43,45,52,75] (Figure 7). A third $\alpha, \alpha, \alpha, \beta$ configuration, in which the $\beta$-interactions are $\mathrm{R}_{2}^{2}(12)$ (reciprocal- $\beta$ ), has also been observed $[18,48,64,69,70]$. The $\alpha, \alpha, \alpha, \gamma$ configuration, with a $\mathrm{R}_{2}^{2}(8)$ reciprocal- $\gamma \mathrm{H}$-bond interaction, is also known [41,75]. There has been one case of an $\alpha, \alpha, \alpha, \alpha$ configuration, [1,2,3$\left.\mathrm{Me}_{3} \mathrm{C}_{3} \mathrm{H}_{2} \mathrm{~N}_{2}\right]\left[\mathrm{B}_{5} \mathrm{O}_{6}(\mathrm{OH})_{4}\right]$ [48]; in principle this should be a favoured configuration, but this anion packing configuration leaves little space for the cation, and in this example the boroxole rings adopt boat conformations to accommodate the cations. The ability of pentaborates to form such strong anionic lattices is an important driving force in their facile synthesis from aqueous solution. There is also sufficient flexibility within the brickwall lattice, and presumably other similar lattices, to accommodate (within limits) cations of various sizes [45]. Table 1 lists interstitial components present within some pentaborate salts. These interstitial components may be innocent and simply fill space within the lattice [45] or, as in other examples, they are structurally active and H-bond to, and/or bridge, pentaborate(1-) anions, leading to unique structures $[26,31,34,40,48,51,52,56,59-63,65-$ 67,75]. It is likely that polyborates other than pentaborates are only formed when the cations cannot fit within the lattice, or when the cations are highly charged, or when there are sufficient cation-anion H-bond interactions to outweigh pentaborate anion-anion interactions $[19,46,96]$. In addition to Hbonds, $\pi \cdots \pi$ stacking interactions have been observed between cations in $\left[\mathrm{Cu}\left(\mathrm{C}_{12} \mathrm{~N}_{2} \mathrm{H}_{8}\right)_{2}\left(\mathrm{MeCO}_{2}\right)\right]\left[\mathrm{B}_{5} \mathrm{O}_{6}(\mathrm{OH})_{4}\right] \cdot \mathrm{C}_{4} \mathrm{H}_{9} \mathrm{NO}$ [67] and in $\left[\mathrm{PPh}_{4}\right]\left[\mathrm{B}_{5} \mathrm{O}_{6}(\mathrm{OH})_{4}\right] \cdot 1.5 \mathrm{H}_{2} \mathrm{O}$ [59] and these further stabilize the solid-state structures. 

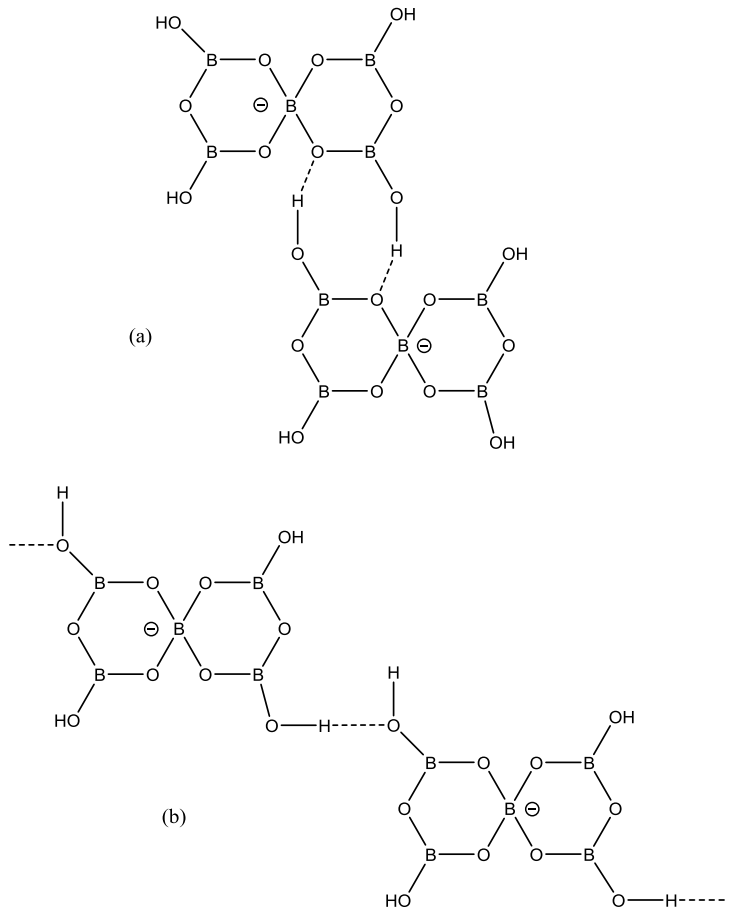

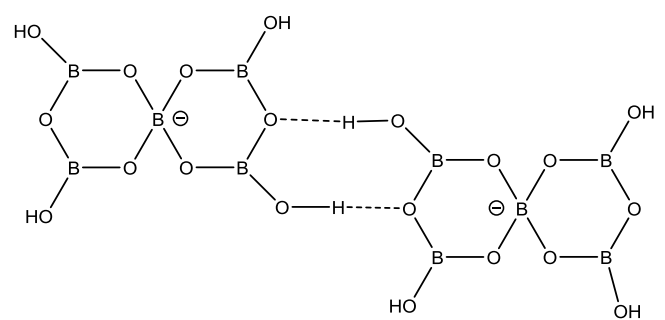

(c)

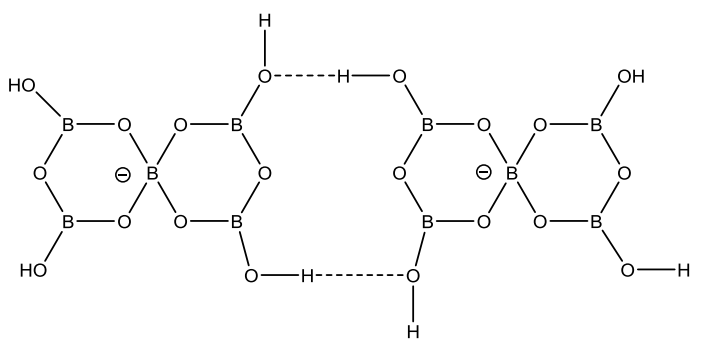

(d)

Figure 6. H-bond interactions commonly found in pentaborate(1-) structures (a) $R_{2}^{2}(8)$ reciprocal- $\alpha$, (b) $C(8) \beta$ chain, (c) $\mathrm{R}_{2}{ }^{2}(8)$ reciprocal- $\gamma$ (d) $\mathrm{R}_{2}{ }^{2}(12)$ reciprocal- $\beta$ [45]. Each H-bond in the $\mathrm{R}_{2}{ }^{2}(8)$ reciprocal- $\alpha$ interaction has been calculated at $-21 \mathrm{~kJ} \mathrm{~mol}^{-1}$.

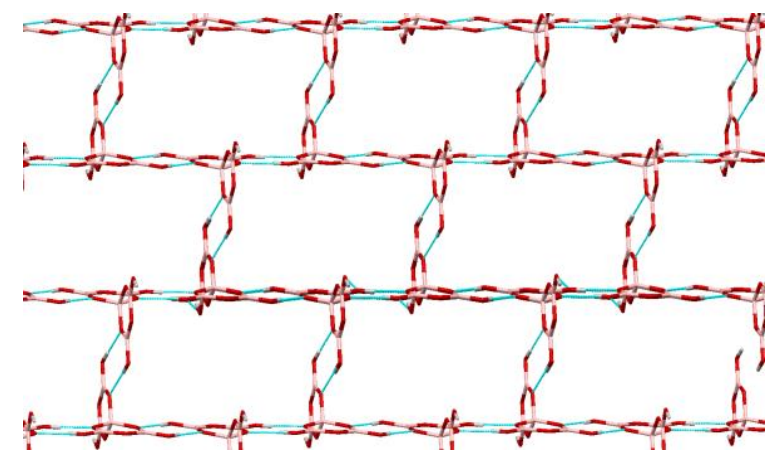

(a)

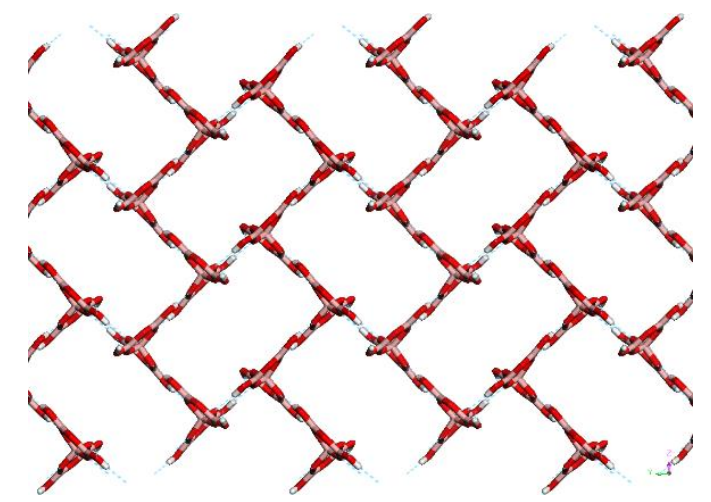

(b)

Figure 7. Pentaborate(1-) networks involving three reciprocal- $\alpha$ H-bonds per pentaborate in $\alpha, \alpha, \alpha, \beta$ systems.

These pack as rectangles (six pentaborates) in planes in either (a) brickwall or (b) herringbone arrangements $[43,76]$. These planes are linked together via $\mathrm{C}(8) \beta$-chain interactions. 
A pentaborate(1-) anion deprotonated at a hydroxyl site is able to coordinate to a $[\mathrm{Zn}(\operatorname{tren})]^{2+}$ (tren $=\operatorname{tris}(2$-aminoethyl)amine $)$ cation in the borate anion/transition-metal complex coordination compound, $\left[\mathrm{Zn}(\operatorname{tren})\left\{\mathrm{OB}_{5} \mathrm{O}_{6}(\mathrm{OH})_{3}\right\}\right]$ where the pentaborate anion is otherwise unchanged [78]. A similar coordination mode is observed in $\left[\mathrm{Co}(\operatorname{tren})\left\{\mathrm{OB}_{5} \mathrm{O}_{6}(\mathrm{OH})_{3}\right\}\right][64]$.

The compound reported as $\left[\mathrm{Ag}(\mathrm{py})_{2}\right]_{2}\left[\mathrm{~B}_{10} \mathrm{O}_{14}(\mathrm{OH})_{4}\right][79]$, is better formulated as $\left[\mathrm{Ag}(\mathrm{py})_{2}\right]\left[\mathrm{B}_{5} \mathrm{O}_{7}(\mathrm{OH})_{2}\right]$ since it contains the one-dimensional poly(pentaborate)(1-) anion, $\left[\left\{\mathrm{B}_{5} \mathrm{O}_{7}(\mathrm{OH})_{2}\right\}_{n}\right]^{\mathrm{n}-}($ Figure $5 \mathrm{~b})$. This can be classified as $5: \infty_{1}(4 \Delta+\mathrm{T})$ or $4 \Delta 1 \square:<2 \Delta \square>-<2 \Delta \square>$. The pentaborate(1-) anions are linked through trigonal boron centres by oxo bridges resulting from the elimination of one water per two pentaborate(1-) anions.

The polymeric pentaborate anion, $\left[\left\{\mathrm{B}_{5} \mathrm{O}_{8}(\mathrm{OH})\right\}_{\mathrm{n}}\right]^{2 \mathrm{n}-}$ (Figure $\left.5 \mathrm{c}\right)$, has been observed in the following compounds: $\left[\mathrm{H}_{3} \mathrm{~N}\left(\mathrm{CH}_{2}\right)_{\mathrm{n}} \mathrm{NH}_{3}\right]\left[\mathrm{B}_{5} \mathrm{O}_{8}(\mathrm{OH})\right](\mathrm{n}=2,3)$ [80-82], $\left[\mathrm{H}_{3} \mathrm{~N}\left(\mathrm{C}_{6} \mathrm{H}_{10}\right) \mathrm{NH}_{3}\right]\left[\mathrm{B}_{5} \mathrm{O}_{8}(\mathrm{OH})\right][83]$ and the metal salts $\mathrm{Sr}\left[\mathrm{B}_{5} \mathrm{O}_{8}(\mathrm{OH})\right] \cdot \mathrm{H}_{2} \mathrm{O}$ [57], $\mathrm{Pb}\left[\mathrm{B}_{5} \mathrm{O}_{8}(\mathrm{OH})\right] \cdot 1.5 \mathrm{H}_{2} \mathrm{O}$ [84]. The polymeric anion is a two-dimensional giant lattice (sheets) which can be classified as $5: \infty_{2}(3 \Delta+2 \mathrm{~T})$ or $3 \Delta 2 \square:<\Delta 2 \square>-<2 \Delta \square>$.

$\alpha, \omega$-Diaminoalkanes coordinated to pentaborates have been prepared, and these contain $\mathrm{N} \rightarrow \mathrm{B}$ dative bonds at boron centres which were previously three coordinate, with the pentaborate(1-) framework remaining intact [85]. Crystallographically determined structures are $\left[\mathrm{B}_{5} \mathrm{O}_{6}(\mathrm{OH})_{4}\left\{\mathrm{NH}_{2}\left(\mathrm{CH}_{2}\right)_{\mathrm{n}} \mathrm{NH}_{3}\right\}\right](\mathrm{n}=5,6)$ and $\left.\left[\mathrm{NH}_{3}\left(\mathrm{CH}_{2}\right)_{8} \mathrm{NH}_{3}\right)\right]\left[\left\{\mathrm{B}_{5} \mathrm{O}_{6}(\mathrm{OH})_{4}\right\}_{2}\left\{\mathrm{NH}_{2}\left(\mathrm{CH}_{2}\right)_{8} \mathrm{NH}_{2}\right\}\right] 2 \mathrm{~B}(\mathrm{OH})_{3} 2 \mathrm{H}_{2} \mathrm{O}$ [85]; the first two structures are zwitterionic and the latter is a salt.

\subsection{Hexaborates}

The hexaborate(2-) anion $(\mathrm{FBB}=6)$ with the descriptors $6: 3 \Delta+3 \mathrm{~T}$ or $3 \Delta 3 \square:[\phi]<\Delta 2 \square>|<\Delta 2 \square>|<\Delta 2 \square>\mid$ is shown in Figure 8. It has been found coordinated (but otherwise unchanged) to a cobalt(2+) ion in the salt [1-cyanopiperazinium] $\left.\left[\mathrm{Co}\left\{\mathrm{B}_{6} \mathrm{O}_{7}(\mathrm{OH})_{6}\right)\right\}_{2}\right]$ [87]. A derivatised hexaborate(2-), containing 
three 2-aminoethoxy groups in place of the -OH groups on the three tetrahedral boron centres (Figure 8) functions as a hexadentate(2-) ligand in the complexes $\left[\mathrm{M}\left(\mathrm{NH}_{2} \mathrm{CH}_{2} \mathrm{CH}_{2} \mathrm{O}\right)_{3} \mathrm{~B}_{6} \mathrm{O}_{7}(\mathrm{OH})_{3}\right](\mathrm{M}=\mathrm{Co}$, Ni) [88].

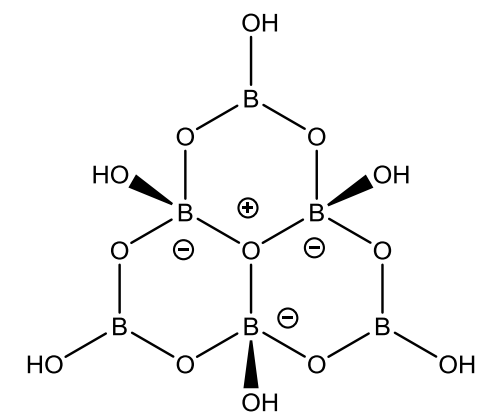

Figure 8. Hexaborate(2-) anion as found in [1-cyanopiperazinium] $\left.\left[\mathrm{Co}\left\{\mathrm{B}_{6} \mathrm{O}_{7}(\mathrm{OH})_{6}\right)\right\}_{2}\right][87]$.

\subsection{Heptaborates}

Three isolated heptaborate anions and two polymeric heptaborate anions were reported during the review period. There are two isomeric isolated heptaborate(2-) anions with the formula $\left[\mathrm{B}_{7} \mathrm{O}_{9}(\mathrm{OH})_{5}\right]^{2-}$ (Figure 9a and 9b). The 'chain' isomer (Figure 9a), can be classified as 7:5 $5+2 \mathrm{~T}$ or $5 \Delta 2 \square:<2 \Delta \square>-$ $<\Delta 2 \square>-<2 \Delta \square>$ and contains three boroxole rings linked through two spiro 4 coordinate boron centres and may be considered an 'extended' pentaborate(1-) system. The ' $\mathrm{O}^{+}$' isomer (Figure 9b), is based on the hexaborate(2-) structure (Figure 8) with a further boric acid condensed with hydroxyl groups on two of the four-coordinate boron centres to form a fourth boroxole ring. Thus the ' $\mathrm{O}^{+}$' structure is based on a hexaborate $(\mathrm{FBB}=6)$ and can be designated as $6:(3 \Delta+3 \mathrm{~T})+\Delta$ or $4 \Delta 3 \square:[\phi]<\Delta 2 \square>|<\Delta 2 \square>|<\Delta 2 \square>\mid=\langle\Delta 2 \square>$. The 'chain' isomer is represented by the metal salts $\mathrm{Rb}_{2}\left[\mathrm{~B}_{7} \mathrm{O}_{9}(\mathrm{OH})_{5}\right][89]$ and $\mathrm{Cs}_{2}\left[\mathrm{~B}_{7} \mathrm{O}_{9}(\mathrm{OH})_{5}\right][90]$, the mixed metal/non-metal cation salt $\mathrm{Na}_{2}\left[\mathrm{H}_{2} \mathrm{tmed}\right]\left[\mathrm{B}_{7} \mathrm{O}_{9}(\mathrm{OH})_{5}\right]_{2}\left(\mathrm{tmed}=N, N, N^{\prime} N^{\prime}\right.$-tetramethylethylenediamine) [91], and non-metal cation salts $\left[\mathrm{H}_{2} \mathrm{dab}\right]\left[\mathrm{B}_{7} \mathrm{O}_{9}(\mathrm{OH})_{5}\right] \cdot \mathrm{H}_{2} \mathrm{O}[92]$ and $\left[\mathrm{H}_{2} \mathrm{en}\right]_{2}\left[\mathrm{~B}_{4} \mathrm{O}_{5}(\mathrm{OH})_{4}\right]\left[\mathrm{B}_{7} \mathrm{O}_{9}(\mathrm{OH})_{5}\right] \cdot 3 \mathrm{H}_{2} \mathrm{O}$ [93]. The latter compound is a unique example of a non-metal cation double salt containing two different 
isolated polyborate anions. The ' $\mathrm{O}^{+}$' isomer is represented by three examples:

$\left[\mathrm{H}_{3} \mathrm{~N}\left(\mathrm{CH}_{2}\right)_{7} \mathrm{NH}_{3}\right]\left[\mathrm{B}_{7} \mathrm{O}_{9}(\mathrm{OH})_{5}\right] \cdot \mathrm{H}_{2} \mathrm{O}$ [94], $\left[\text { cyclo- } \mathrm{C}_{6} \mathrm{H}_{11} \mathrm{NH}_{3}\right]_{2}\left[\mathrm{~B}_{7} \mathrm{O}_{9}(\mathrm{OH})_{5}\right] \cdot 3 \mathrm{H}_{2} \mathrm{O} \cdot \mathrm{B}(\mathrm{OH})_{3}[95]$ and [cyclo- $\left.\mathrm{C}_{7} \mathrm{H}_{13} \mathrm{NH}_{3}\right]_{2}\left[\mathrm{~B}_{7} \mathrm{O}_{9}(\mathrm{OH})_{5}\right] \cdot 2 \mathrm{H}_{2} \mathrm{O} 2 \mathrm{~B}(\mathrm{OH})_{3}[95]$. The anions in the cyclo-alkylammonium derivatives form hexagonal honeycomb columns with the boric acid units incorporated within the columns functioning as spacers to allow for the cations to fit, as stacks, within the lattice.

The isolated heptaborate(3-) anion, $\left[\mathrm{B}_{7} \mathrm{O}_{9}(\mathrm{OH})_{6}\right]^{3-}($ Figure 9c), is related to the 'chain' heptaborate(2-) anion in that it possesses an additional hydroxyl group on an outer boroxole ring, converting a previously three-coordinate boron atom to a four-coordinate centre. This anion is classified as $7: 4 \Delta+3 \mathrm{~T}$ or $4 \Delta 3 \square:<2 \Delta \square>-<\Delta 2 \square>-<\Delta 2 \square>$. The transition-metal complex cation salt $\left[\mathrm{Co}(\text { dien })_{2}\right]\left[\mathrm{B}_{7} \mathrm{O}_{9}(\mathrm{OH})_{6}\right] \cdot 9 \mathrm{H}_{2} \mathrm{O}$ contains this anion [96].

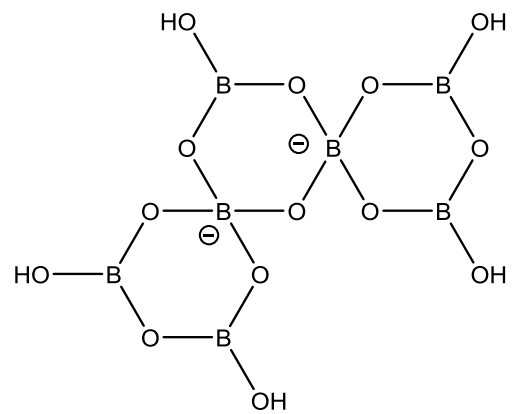

(a)

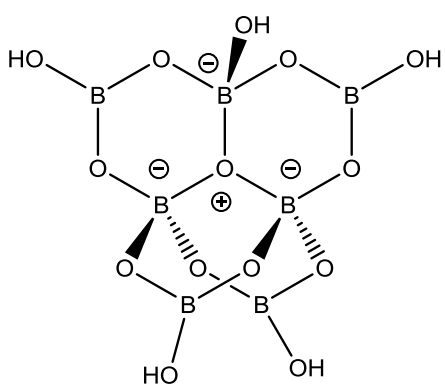

(b)

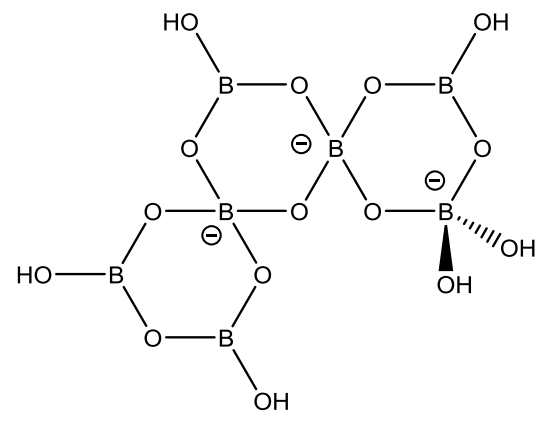

(c)

Figure 9. Isolated heptaborate anions as found in (a) $\left[\mathrm{H}_{2} \mathrm{dab}\right]\left[\mathrm{B}_{7} \mathrm{O}_{9}(\mathrm{OH})_{5}\right] \cdot \mathrm{H}_{2} \mathrm{O}[$ [92], (b)

$\left[\mathrm{H}_{3} \mathrm{~N}\left(\mathrm{CH}_{2}\right)_{7} \mathrm{NH}_{3}\right]\left[\mathrm{B}_{7} \mathrm{O}_{9}(\mathrm{OH})_{5}\right] \cdot \mathrm{H}_{2} \mathrm{O}$ [94] and (c) $\left[\mathrm{Co}(\text { dien })_{2}\right]\left[\mathrm{B}_{7} \mathrm{O}_{9}(\mathrm{OH})_{6}\right] \cdot 9 \mathrm{H}_{2} \mathrm{O}$ [96]. 
Polymeric heptaborate(2-) anions, of stoichiometry $\left[\mathrm{B}_{7} \mathrm{O}_{10}(\mathrm{OH})_{3}\right]^{2-}$ are represented by two compounds: $\left[\mathrm{Cu}(\mathrm{en})_{2}\right]\left[\mathrm{B}_{7} \mathrm{H}_{10}(\mathrm{OH})_{3}\right]$ [97] (Figure 10a) and $\left[\mathrm{H}_{3} \mathrm{~N}\left(\mathrm{CH}_{2}\right)_{6} \mathrm{NH}_{3}\right]\left[\mathrm{B}_{7} \mathrm{H}_{10}(\mathrm{OH})_{3}\right]$ [98] (Figure 10b). Both anionic lattices are arranged in sheets and are described as $\infty_{2}\{3:(2 \Delta+\mathrm{T})+\Delta+3:(2 \Delta+\mathrm{T})\}$ and $\infty_{2}\{6:(3 \Delta+3 \mathrm{~T})+\Delta\}$, respectively, since the former is based on two triborate(1-) building blocks ( $\mathrm{FBB}=3$ ) bridged by a monoborate, and the latter is based on a hexaborate $(2-)(\mathrm{FBB}=6)$ with a pendant monoborate $(\mathrm{FBB}=1)$. Alternative Burns' descriptors are $5 \Delta 2 \square:<2 \Delta \square>\Delta<2 \Delta \square>$ and $4 \Delta 3 \square:[\phi]<\Delta 2 \square>|<\Delta 2 \square>|<\Delta 2 \square>\mid \Delta$, respectively. The OH groups on the boroxole rings atoms are weakly coordinated to axial positions of the $\left[\mathrm{Cu}(\mathrm{en})_{2}\right]^{2+}$ cations in $\left[\mathrm{Cu}(\mathrm{en})_{2}\right]\left[\mathrm{B}_{7} \mathrm{H}_{10}(\mathrm{OH})_{3}\right]$.

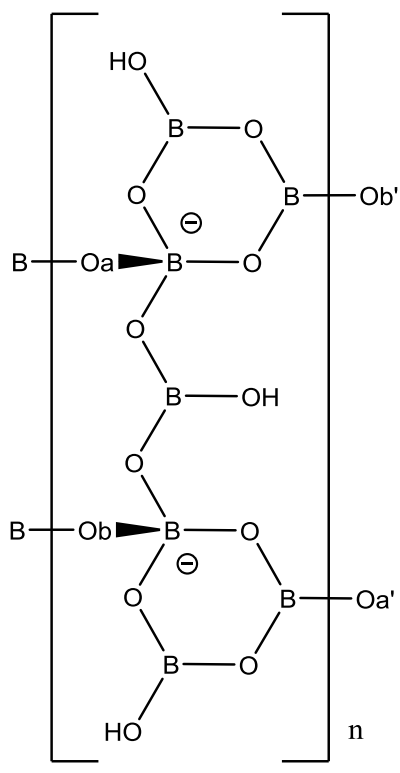

(a)

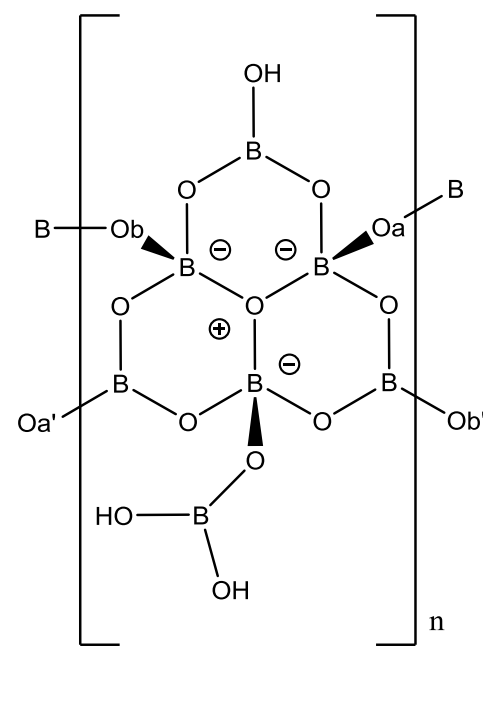

(b)

Figure 10. Polymeric heptaborate(2-) anions found in (a) $\left[\mathrm{Cu}(\mathrm{en})_{2}\right]\left[\mathrm{B}_{7} \mathrm{H}_{10}(\mathrm{OH})_{3}\right]$ [97] and (b) $\left[\mathrm{H}_{3} \mathrm{~N}\left(\mathrm{CH}_{2}\right)_{6} \mathrm{NH}_{3}\right]\left[\mathrm{B}_{7} \mathrm{H}_{10}(\mathrm{OH})_{3}\right][98]$. 


\subsection{Octaborates}

Two isolated octaborate(2-) anions and one polymeric octaborate(2-) anion have been structurally determined over the review period. The isolated anions both have stoichiometry $\left[\mathrm{B}_{8} \mathrm{O}_{10}(\mathrm{OH})_{6}\right]^{2-}$ and these are represented by $\left[\mathrm{H}_{3} \mathrm{~N}\left(\mathrm{CH}_{2}\right)_{7} \mathrm{NH}_{3}\right]\left[\mathrm{B}_{8} \mathrm{O}_{10}(\mathrm{OH})_{6}\right] 2 \mathrm{~B}(\mathrm{OH})_{3}[40]$ and $\left[\mathrm{Co}(\mathrm{en})_{3}\right]\left[\mathrm{B}_{5} \mathrm{O}_{6}(\mathrm{OH})_{4}\right]\left[\mathrm{B}_{8} \mathrm{O}_{10}(\mathrm{OH})_{6}\right] .5 \mathrm{H}_{2} \mathrm{O}[62] . \quad\left[\mathrm{H}_{3} \mathrm{~N}\left(\mathrm{CH}_{2}\right)_{7} \mathrm{NH}_{3}\right]\left[\mathrm{B}_{8} \mathrm{O}_{10}(\mathrm{OH})_{6}\right] \cdot 2 \mathrm{~B}(\mathrm{OH})_{3}($ Figure 11a) can be considered derived from a formal condensation of a pentaborate(1-) anion with a triborate(1-) yielding an oxo bridged species with three boroxole rings. This octaborate(2-) anion can be classified as $5:(4 \Delta+\mathrm{T})+3:(2 \Delta+\mathrm{T})$ or $6 \Delta 2 \square:<2 \Delta \square>-$ $\langle 2 \Delta \square\rangle\langle 2 \Delta \square\rangle$. $\left[\mathrm{Co}(\mathrm{en})_{3}\right]\left[\mathrm{B}_{5} \mathrm{O}_{6}(\mathrm{OH})_{4}\right]\left[\mathrm{B}_{8} \mathrm{O}_{10}(\mathrm{OH})_{6}\right] \cdot 5 \mathrm{H}_{2} \mathrm{O}$ is a unique transition-metal cation salt in that it contains two isolated polyborate anions. The octaborate(2-) anion, Figure 11b, possesses a three-coordinate oxygen atom, and four boroxole rings, and it can be considered to be constructed from fused tetraborate(2-) and pentaborate(1-) anions with two oxygen atoms and one boron atom in common. It can be classified as 8:5 $5+3 \mathrm{~T}$ or $5 \Delta 3 \square:\langle\Delta 2 \square>=\langle\Delta 2 \square>-<\Delta 2 \square>-\langle 2 \Delta \square>$.

A one-dimensional polymeric octaborate(2-) anion chain (Figure 11c) is observed in the nonmetal cation salt $\left[\mathrm{H}_{3} \mathrm{NCH}_{2} \mathrm{CHCH}_{3} \mathrm{NH}_{3}\right]\left[\mathrm{B}_{8} \mathrm{O}_{11}(\mathrm{OH})_{4}\right] \cdot \mathrm{H}_{2} \mathrm{O}$ [99]. The polymeric chain can be viewed as a polymeric triborate $(1-)(\mathrm{FBB}=3)$ linked by an oxo bridge to a pendant pentaborate(1-) residue $(\mathrm{FBB}=5)$, via the triborate tetrahedral boron centre. It can be classified as $\infty_{1}\{5:(4 \Delta+\mathrm{T})+3:(2 \Delta+\mathrm{T})\}$ or $6 \Delta 2 \square:<2 \Delta \square>-<2 \Delta \square><2 \Delta \square>$. 
<smiles>OB1OB(O)OB(O[P]2(O)OB(O)OB(O)O2)O1</smiles>

(a)

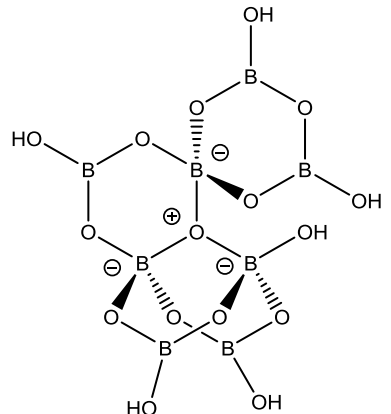

(b)

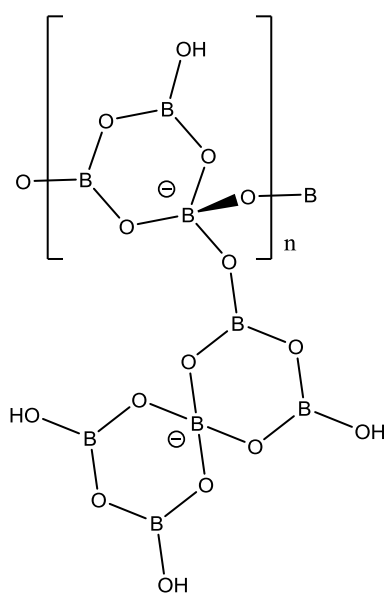

(c)

Figure 11. Isolated octaborate(2-) anions as found in (a) $\left[\mathrm{H}_{3} \mathrm{~N}\left(\mathrm{CH}_{2}\right)_{7} \mathrm{NH}_{3}\right]\left[\mathrm{B}_{8} \mathrm{O}_{10}(\mathrm{OH})_{6}\right] \cdot 2 \mathrm{~B}(\mathrm{OH})_{3}[40]$ and (b) $\left[\mathrm{Co}(\mathrm{en})_{3}\right]\left[\mathrm{B}_{5} \mathrm{O}_{6}(\mathrm{OH})_{4}\right]\left[\mathrm{B}_{8} \mathrm{O}_{10}(\mathrm{OH})_{6}\right] \cdot 5 \mathrm{H}_{2} \mathrm{O}[62]$, and (c) the polymeric octaborate(2-) anion found in $\left[\mathrm{H}_{3} \mathrm{NCH}_{2} \mathrm{CHCH}_{3} \mathrm{NH}_{3}\right]\left[\mathrm{B}_{8} \mathrm{O}_{11}(\mathrm{OH})_{4}\right] \cdot \mathrm{H}_{2} \mathrm{O}[99]$.

\subsection{Nonaborates}

Examples of compounds containing a nonaborate anion are rare and are limited to the isolated nonaborate(3-) anion (Figure 12) partnered with either the guanidinium or imidazolium cation: $\left[\mathrm{C}\left(\mathrm{NH}_{2}\right)_{3}\right]_{3}\left[\mathrm{~B}_{9} \mathrm{O}_{12}(\mathrm{OH})_{6}\right][10,100],\left[\mathrm{C}_{3} \mathrm{H}_{5} \mathrm{~N}_{2}\right]_{3}\left[\mathrm{~B}_{9} \mathrm{O}_{12}(\mathrm{OH})_{6}\right][10,100]$. The nonaborate(3-) anion is comprised of four boroxole rings linked by three four-coordinate boron centres in an extended chain configuration ( $c f$. pentaborate(1-) and 'chain' heptaborate(2-) anions). The structure can be described as $9: 6 \Delta+3 \mathrm{~T}$ or $6 \Delta 3 \square:<2 \Delta \square>-<\Delta 2 \square>-<\Delta 2 \square>-<2 \Delta \square>$. 


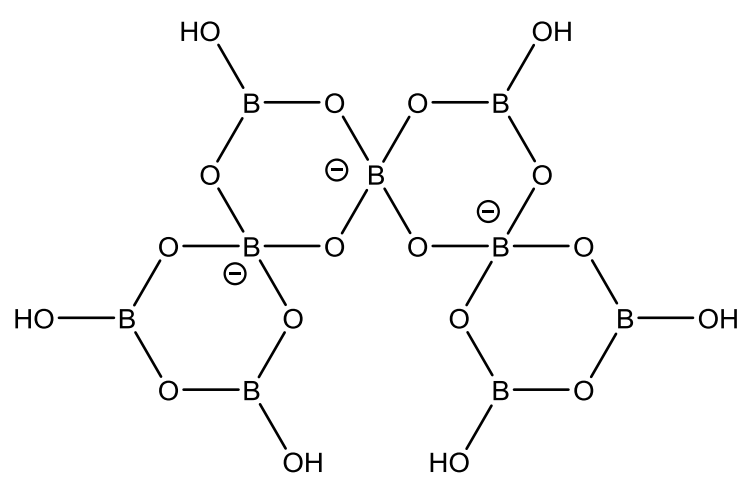

Figure 12 . Nonaborate(3-) anion found in [guanidinium $]_{3}\left[\mathrm{~B}_{9} \mathrm{O}_{12}(\mathrm{OH})_{6}\right][100]$.

\subsection{Larger polyborate anions}

The compound $\left[\mathrm{Ag}(\mathrm{py})_{2}\right]_{2}\left[\mathrm{~B}_{10} \mathrm{O}_{14}(\mathrm{OH})_{4}\right]$ has been reported as having a one-dimensional polyborate chain [79]. It is described under Section 3.4 since it is a polymeric pentaborate(1-) rather than a polymeric decaborate(2-).

One compound has been formulated as an undecaborate but its crystallographic structure revealed that it was a double salt containing both isolated tetraborate(2-) and isolated heptaborate(2-) anions [25].

A new potassium borate has been prepared containing an isolated dodecaborate(4-) anion: $\mathrm{K}_{4}\left[\mathrm{~B}_{12} \mathrm{O}_{16}(\mathrm{OH})_{8}\right][22]$. The structure of this cyclic anion is shown in Figure 13a where it can be seen to be based on tetrameric triborate $(\mathrm{FBB}=3)$ unit and is comprised of four boroxole rings linked by oxygen atoms bridging three-coordinate and four-coordinate boron centres. It can be classified as $\{3:(2 \Delta+\mathrm{T})\}_{4}$ or $\{2 \Delta \square:(2 \Delta \square)\}_{4}$. The isolated $\left[\mathrm{B}_{12} \mathrm{O}_{18}(\mathrm{OH})_{6}\right]^{6-}$ anion (Figure 13b) is based on a hexameric triborate $(\mathrm{FBB}=3)$ unit and is classified as $\{3:(\Delta+2 \mathrm{~T})\}_{6}$ or $\{\Delta 2 \square:(\Delta 2 \square)-\}_{6}$. This anion has been observed to coordinate in a tridentate manner to a manganese(2+) ion through three (alternate) of the six bridging oxygen atoms between four-coordinate boron centres of the hexameric dodecaborate(6-) ligand in the compound $\mathrm{K}_{7}\left[\left(\mathrm{BO}_{3}\right) \mathrm{Mn}\left\{\mathrm{B}_{12} \mathrm{O}_{18}(\mathrm{OH})_{6}\right\}\right] \cdot \mathrm{H}_{2} \mathrm{O}$ [101]. The manganese $(2+)$ centre is five-coordinate with the monoborate(3-) ligand bidentate to the metal centre. The analogous zinc(2+) derivative, $\mathrm{K}_{7}\left[\left(\mathrm{BO}_{3}\right) \mathrm{Zn}\left\{\mathrm{B}_{12} \mathrm{O}_{18}(\mathrm{OH})_{6}\right\}\right] \cdot \mathrm{H}_{2} \mathrm{O}$ has also been reported [102]. 


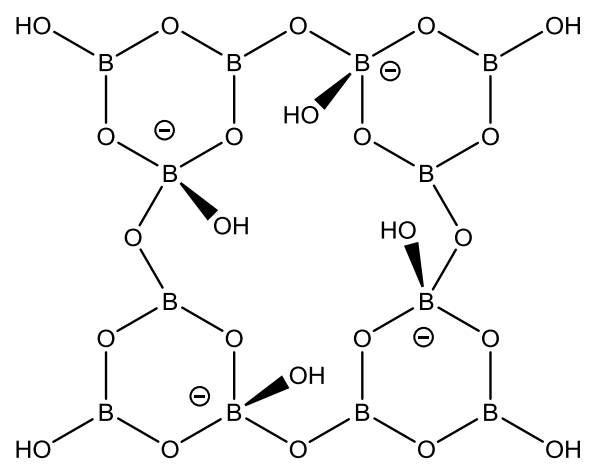

(a)

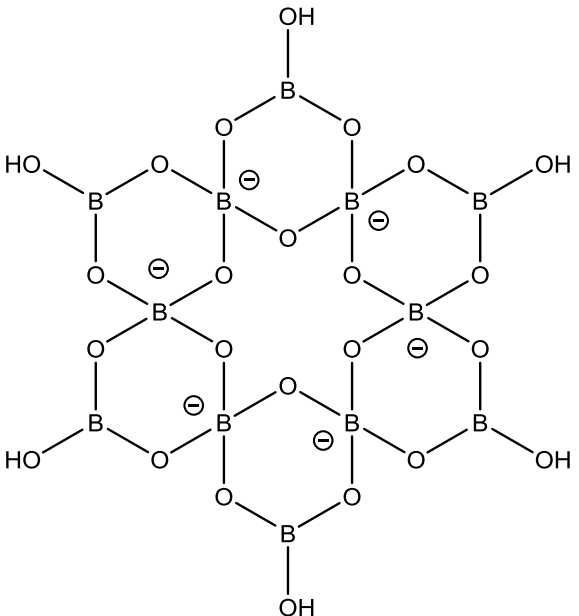

(b)

Figure 13. (a) The dodecaborate(4-) found in $\mathrm{K}_{4}\left[\mathrm{~B}_{12} \mathrm{O}_{16}(\mathrm{OH})_{8}\right]$ [22] and (b) the dodecaborate(6-) found in $\mathrm{K}_{7}\left[\left(\mathrm{BO}_{3}\right) \mathrm{Mn}\left\{\mathrm{B}_{12} \mathrm{O}_{18}(\mathrm{OH})_{6}\right\}\right] \cdot \mathrm{H}_{2} \mathrm{O}[101]$.

Several non-metal cation salts of the isolated tetradecaborate(4-) anion (Figure 14) have been prepared: $\left[\mathrm{H}_{2} \mathrm{dien}\right]_{2}\left[\mathrm{~B}_{14} \mathrm{O}_{20}(\mathrm{OH})_{6}\right][89],\left[\mathrm{H}_{3} \mathrm{~N}\left(\mathrm{CH}_{2}\right)_{\mathrm{n}} \mathrm{NH}_{3}\right]_{2}\left[\mathrm{~B}_{14} \mathrm{O}_{20}(\mathrm{OH})_{6}\right](\mathrm{n}=2[34,103] \mathrm{n}=3,6[104]$ and $\mathrm{n}=4$ [92]). The anion can be seen to be comprised of two 'chain' isolated heptaborate(2-) anions condensed with the elimination of two equivalents of water. The anion has a FBB $=7$ and classified as $\{7:(5 \Delta+\mathrm{T})\}_{2}$ or $(5 \Delta 2 \square) 2:(<2 \Delta \square>-<\Delta 2 \square>-<2 \Delta \square>)_{2}$

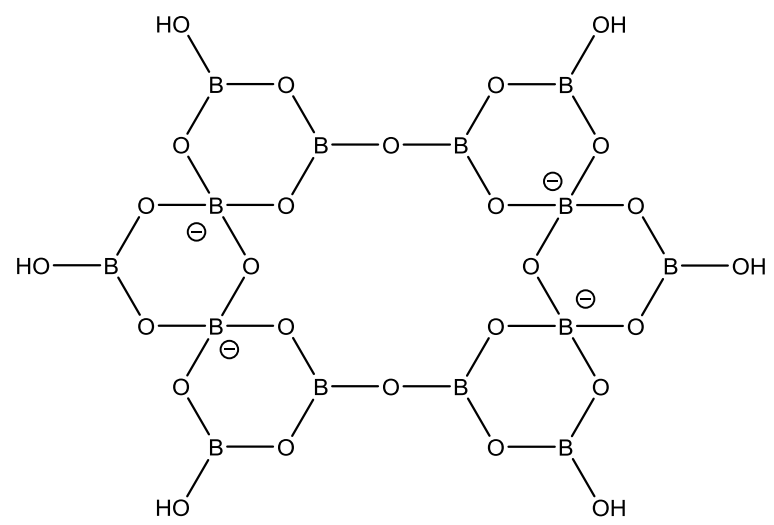

Figure 14. Tetradecaborate(4-) anion as found in $\left[\mathrm{H}_{3} \mathrm{~N}\left(\mathrm{CH}_{2}\right)_{2} \mathrm{NH}_{3}\right]_{2}\left[\mathrm{~B}_{14} \mathrm{O}_{20}(\mathrm{OH})_{6}\right][34,102]$. 
The mineral ammonioborite, $\left[\mathrm{NH}_{4}\right]_{3}\left[\mathrm{~B}_{15} \mathrm{O}_{20}(\mathrm{OH})_{8}\right] \cdot 4 \mathrm{H}_{2} \mathrm{O}$, contains the isolated pentadecaborate(3-) anion. This anion can be classified as $5:(4 \Delta+\mathrm{T})+5:(4 \Delta+\mathrm{T})+5:(4 \Delta+\mathrm{T})$ or $12 \Delta 3 \square:\langle 2 \Delta \square>-<2 \Delta \square><2 \Delta \square>-<2 \Delta \square><2 \Delta \square>-<2 \Delta \square>$. It results from the condensation of three pentaborate(1-) anions, with elimination of two water molecules, leaving oxo bridges between pentaborate moieties (Figure 15). The compounds thermal behaviour has been studied by thermal XRD and DTA methods [105]. The thermal decomposition of the mineral proceeds in several steps and its thermal expansion is anisotropic.

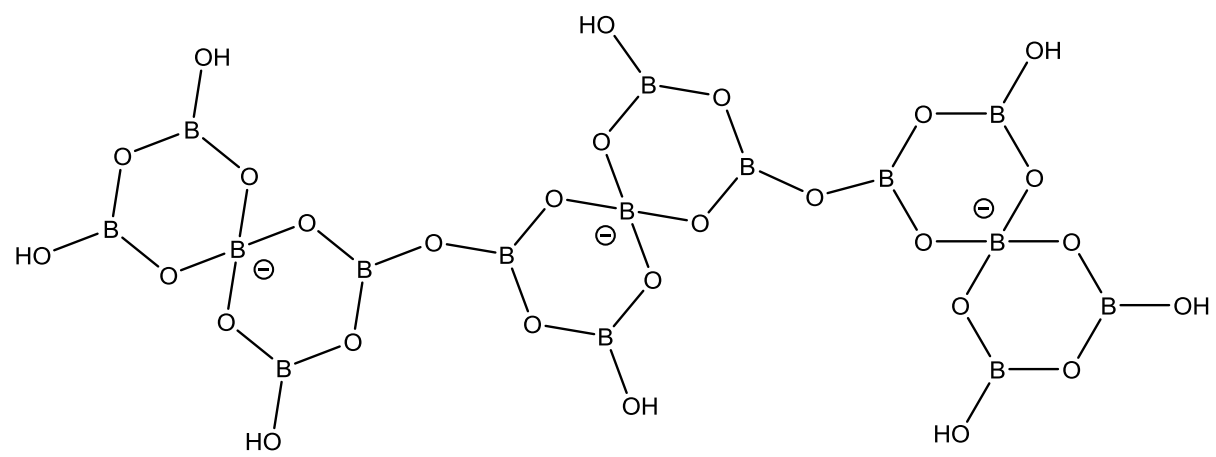

Figure 15. Pentadecaborate(3-) anion as found in $\left(\mathrm{NH}_{4}\right)_{3}\left[\mathrm{~B}_{15} \mathrm{O}_{20}(\mathrm{OH})_{8}\right] \cdot 4 \mathrm{H}_{2} \mathrm{O}[105]$.

\subsection{Synthetic methods}

With the exception of pentaborate(1-) salts, which are readily prepared from mixing reagents in a 5:1 ratio in aqueous solution and awaiting crystallization, the planned synthesis of salts containing particular polyborate anions is rare and synthetic reactions sometimes lead to salts with unexpected borate stoichiometry. This may be explained since in aqueous solution under typical reaction conditions the 'borate component' of the reactant exists as a Dynamic Combinatorial Library [106] of various polyborate anions, which are in equilibrium with concentrations as determined by total boron concentration, temperature and $\mathrm{pH}$ [107]. The cation plays an important part in templating the product which, through a self-assembly process, eventually crystallizes from the solution, since it is 
the energetics of the solid-state structure, usually dominated by crystal packing and by interionic $\mathrm{H}$ bond interactions, which determines the stoichiometry and structure of the product (see Section 3.4).

The majority of compounds described in this review have been prepared in aqueous solution by simply mixing reactants $[10,16-19,25,27,31,39-41,43-45,48,50,52,54,56,59,62,75,87,93,95,96,100]$ or by use of hydrothermal $[20,22,26,28,30,32,34,37,47,53,57,63-65,70-72,79,82,84,102,115]$ or solvothermal $[35,36,38,42,46,50,51,55,60,66,68,69,80,81,83,89,91,92,98,101,104,108]$ methods. A typical hydrothermal method, as used for $\left[\mathrm{H}_{3} \mathrm{NCH}_{2} \mathrm{CHCH}_{3} \mathrm{NH}_{3}\right]\left[\mathrm{B}_{8} \mathrm{O}_{11}(\mathrm{OH})_{4}\right] \cdot \mathrm{H}_{2} \mathrm{O}$ [99], is as follows: a mixture of boric acid $(0.96 \mathrm{~g})$, water $(0.2 \mathrm{~mL})$ and 1,2-diaminopropane $(0.4 \mathrm{~mL})$ were sealed in a Teflon lined stainless steel autoclave and heated at $180{ }^{\circ} \mathrm{C}$ for 7 days under autogenous pressure, and then cooled to room temperature to afford colourless crystals. The solvothermal method, illustrated $\left[\mathrm{H}_{3} \mathrm{~N}\left(\mathrm{CH}_{2}\right)_{6} \mathrm{NH}_{3}\right]\left[\mathrm{B}_{7} \mathrm{O}_{10}(\mathrm{OH})_{3}\right]$ [98 ], is as follows: a $50 \mathrm{~mL}$ Teflon lined stainless steel autoclave loaded with boric acid (12.0 g, $194 \mathrm{mmol}), 1,6$-diaminohexane $(6.0 \mathrm{~g}, 50.8 \mathrm{mmol})$ and ethanol (15 $\mathrm{mL}$ ) was heated at $150{ }^{\circ} \mathrm{C}$ for 5 days and then cooled to room temperature at $5{ }^{\circ} \mathrm{C} /$ hour to afford colourless crystals. In the lists above, the terms 'hydrothermal' and 'solvothermal' are those used by the authors in the publications cited although in many cases a mixed solvent/water liquid phase is used and these terms appear to be used interchangeably. Thus for example, $\left[\mathrm{Co}(\operatorname{dien})_{2}\right]\left[\mathrm{B}_{5} \mathrm{O}_{6}(\mathrm{OH})_{4}\right]_{2}$ was prepared 'hydrothermally' from a mixture of cobalt(II) acetate tetrahydrate, boric acid, pyridine, and water in a molar ratio of 1:3.2:40:30 at $160{ }^{\circ} \mathrm{C}$ in a Teflon lined stainless steel autoclave for 7 days [64]. There are a few reports $[58,85,90,94]$ in which 'solvent' is absent $e . g$. $\left[\mathrm{H}_{3} \mathrm{~N}\left(\mathrm{CH}_{2}\right)_{7} \mathrm{NH}_{3}\right]\left[\mathrm{B}_{7} \mathrm{O}_{9}(\mathrm{OH})_{5}\right] \cdot \mathrm{H}_{2} \mathrm{O}[94]$ was synthesised by heating a gum, prepared in a mortar and pestle from boric acid $(0.07 \mathrm{~mol})$ and 1,7-diaminoheptane $(0.01 \mathrm{~mol})$, in a sealed tube for $16 \mathrm{~h}$ at 80 ${ }^{\circ} \mathrm{C}$. A 'flux' method $[97,103]$ has also been described e.g. for $\left[\mathrm{Cu}(\mathrm{en})_{2}\right]\left[\mathrm{B}_{7} \mathrm{H}_{10}(\mathrm{OH})_{3}\right][97]$ a Teflon lined pressure vessel was charged with copper(II) nitrate trihydrate $(270 \mathrm{mg}), 1,2$-diaminoethane and boric acid (molar ratio 1:3:13), and heated for 3 days at $180{ }^{\circ} \mathrm{C}$. Interestingly, a parallel hydrothermal method gave $\left[\mathrm{Cu}(\mathrm{en})_{2}\left\{\mathrm{~B}(\mathrm{OH})_{3}\right\}\right]\left[\mathrm{B}_{4} \mathrm{O}_{5}(\mathrm{OH})_{4}\right] \cdot \mathrm{B}(\mathrm{OH})_{3}[28]$. 


\subsection{Physical and spectroscopic properties}

The most thoroughly investigated property of polyborate salts is their thermal (TGA/DSC) behaviour $[10,18,20,21,24,34,39,41,43,45,48,53,56-60,63,65,66,70,74,78,81,83,95,99,100,108,115]$. The behaviour of non-metal cation polyborate salts in air is typified by that observed for the pyrrolidinium pentaborate $\left[\mathrm{C}_{4} \mathrm{H}_{8} \mathrm{NH}_{2}\right]\left[\mathrm{B}_{5} \mathrm{O}_{6}(\mathrm{OH})_{4}\right][45]$. This salt shows dehydration (endothermic process) to yield an anhydrous polymeric polyborate at $200-250{ }^{\circ} \mathrm{C}$. At higher temperatures $\left(400-800{ }^{\circ} \mathrm{C}\right)$ oxidation of the organic components of the salt occurs through an exothermic process. These two processes are shown in Equations 1-2.

(Eqn. 1) $\quad\left[\mathrm{C}_{4} \mathrm{H}_{8} \mathrm{NH}_{2}\right]\left[\mathrm{B}_{5} \mathrm{O}_{6}(\mathrm{OH})_{4}\right] \rightarrow\left[\mathrm{C}_{4} \mathrm{H}_{8} \mathrm{NH}_{2}\right]\left[\mathrm{B}_{5} \mathrm{O}_{8}\right]+2 \mathrm{H}_{2} \mathrm{O}$

(Eqn. 2) $\quad\left[\mathrm{C}_{4} \mathrm{H}_{8} \mathrm{NH}_{2}\right]\left[\mathrm{B}_{5} \mathrm{O}_{8}\right]+$ excess $\mathrm{O}_{2} \rightarrow 2.5 \mathrm{~B}_{2} \mathrm{O}_{3}+$ volatile oxidation products

Should the salt possess interstitial water, e.g. $\left[\mathrm{H}_{3} \mathrm{~N}\left(\mathrm{CH}_{2}\right)_{7} \mathrm{NH}_{3}\right]\left[\mathrm{B}_{7} \mathrm{O}_{9}(\mathrm{OH})_{5}\right] \cdot \mathrm{H}_{2} \mathrm{O}$ [98], then this water is lost at low temperature $\left(<150{ }^{\circ} \mathrm{C}\right)$ prior to dehydration of the polyborate $[40,59]$. In many cases the materials are reported to char and intumesce prior to collapsing down to a glassy solid $[17,18,43,45,56,98]$. The identity of the glassy solid is boron oxide, $\mathrm{B}_{2} \mathrm{O}_{3}$. BET analyses of the anhydrous borates, intumesced materials and the residual boron oxides have demonstrated that they are all non-porous $[18,43,45,56]$. TGA/DSC data for compounds heated under argon or dinitrogen are very similar $[40,58,64,72,76-78]$ yielding boron oxide in the final step through thermal decomposition of the organic components.

Polyborate salts with metal-complexes as cations decompose in a similar fashion $[26,62,66,70]$, yielding glassy solids which are polymeric anhydrous metal borates e.g. $\left[\mathrm{Ni}(\mathrm{en})_{2}(\right.$ pip) $]\left[\mathrm{B}_{5} \mathrm{O}_{6}(\mathrm{OH})_{4}\right]_{2}$ affords $\mathrm{NiB}_{10} \mathrm{O}_{16}$ as a residue after prolonged heating [70], and 
$\left[\mathrm{Co}(\mathrm{en})_{3}\right]\left[\mathrm{B}_{5} \mathrm{O}_{6}(\mathrm{OH})_{4}\right]\left[\mathrm{B}_{8} \mathrm{O}_{10}(\mathrm{OH})_{6}\right] \cdot 5 \mathrm{H}_{2} \mathrm{O}$ yields $\mathrm{CoB}_{13} \mathrm{O}_{21}[62] . \mathrm{Zn}\left[\mathrm{B}_{3} \mathrm{O}_{3}(\mathrm{OH})_{3}\right]$ is an industrially important compound with uses as a polymer additive (fire redardant synergist, char promotor, smoke and afterglow suppressant) and as a preservative in wood composites [21]. The thermochemical properties of $\mathrm{Zn}\left[\mathrm{B}_{3} \mathrm{O}_{3}(\mathrm{OH})_{3}\right]$ has been investigated [21]. Dehydration commences above $290{ }^{\circ} \mathrm{C}$, to yield an amorphous material of composition $2 \mathrm{ZnO} 3 \mathrm{~B}_{2} \mathrm{O}_{3}$ and at $640{ }^{\circ} \mathrm{C}$ two anhydrous zinc borate phases $\left(3 \mathrm{ZnO} \cdot \mathrm{B}_{2} \mathrm{O}_{3}\right.$ and $\left.4 \mathrm{ZnO} \cdot 3 \mathrm{~B}_{2} \mathrm{O}_{3}\right)$ crystallize out in the presence of liquid $\mathrm{B}_{2} \mathrm{O}_{3}$.

Optical absorption spectral (UV/VIS) investigation of $\left[\mathrm{NH}_{3}\left(\mathrm{CH}_{2}\right)_{\mathrm{n}} \mathrm{NH}_{3}\right]\left[\mathrm{B}_{14} \mathrm{O}_{20}(\mathrm{OH})_{6}\right](\mathrm{n}=2$, 6) and $\left[\mathrm{Ni}(\text { dien })_{2}\right]\left[\mathrm{B}_{5} \mathrm{O}_{6}(\mathrm{OH})_{4}\right]_{2}$ indicates that they are wide-band-gap semiconductors $[71,103]$ and fluorescence spectroscopy indicates that the tetradecaborates are potential blue light materials [103]. The luminescent properties of some synthetic pentaborates have been investigated and $\left[\mathrm{M}(\text { dap })_{3}\right]\left[\mathrm{B}_{5} \mathrm{O}_{6}(\mathrm{OH})_{4}\right] \cdot \mathrm{H}_{2} \mathrm{O}(\mathrm{M}=\mathrm{Co}, \mathrm{Ni}$; dap = 1,2-diaminopropane $)$ both show blue luminescence (405 and $408 \mathrm{~nm}$ ) upon UV excitation [63]. The 4,4'-bipyridinium salt, $\left[\mathrm{C}_{10} \mathrm{~N}_{2} \mathrm{H}_{9}\right]\left[\mathrm{B}_{5} \mathrm{O}_{6}(\mathrm{OH})_{4}\right] \cdot \mathrm{B}(\mathrm{OH})_{3} \mathrm{H}_{2} \mathrm{O}$, shows $\mathrm{UV}$ photoluminescence with emission maximum at 372 $\mathrm{nm}$ which can be modified to blue by means of a simple heat treatment [54]. Blue luminescence is shown for $[$ cyclo-hexylamine $]\left[\mathrm{B}_{5} \mathrm{O}_{6}(\mathrm{OH})_{4}\right]$ upon UV excitation [115]; this can be enhanced and modified to near-white by a thermal treatment. The $N$-butylpyridinium salt $\left[\mathrm{C}_{9} \mathrm{H}_{14} \mathrm{~N}\right]\left[\mathrm{B}_{5} \mathrm{O}_{6}(\mathrm{OH})_{4}\right]$ exhibits tunable luminescence emission at $415-458 \mathrm{~nm}$ by means of heat treatment from $100-300{ }^{\circ} \mathrm{C}$ [53]. Heat treatment of [ $\left.\mathrm{PrMe}_{3} \mathrm{~N}\right]\left[\mathrm{B}_{5} \mathrm{O}_{6}(\mathrm{OH})_{4}\right]$ [I44] shifts the luminescence from blue to white and a sample treated at $230{ }^{\circ} \mathrm{C}$ emits bright white light to the naked eye [37].

Some polyborates have been shown to exhibit fluorescent properties e.g. [1cyanopiperazinium] $\left[\mathrm{Co}\left\{\left(\mathrm{B}_{6} \mathrm{O}_{7}(\mathrm{OH})_{6}\right\}_{2}\right][87], \mathrm{Na}_{2}\left[\mathrm{H}_{2} \mathrm{tmed}\right]\left[\mathrm{B}_{7} \mathrm{O}_{9}(\mathrm{OH})_{5}\right]_{2}[35]\right.$ and $\left[{ }^{i} \operatorname{PrMe}_{3} \mathrm{~N}\right]\left[\mathrm{B}_{5} \mathrm{O}_{6}(\mathrm{OH})_{4}\right]$ [37]. The fluorescent intensity of [ $\left.{ }^{i} \operatorname{PrMe}_{3} \mathrm{~N}\right]\left[\mathrm{B}_{5} \mathrm{O}_{6}(\mathrm{OH})_{4}\right]$ enhances six-fold with decreasing temperature [37].

Non-linear optical (NLO) properties have been reported for $\left[\mathrm{C}_{6} \mathrm{H}_{13} \mathrm{~N}_{2}\right]\left[\mathrm{B}_{5} \mathrm{O}_{6}(\mathrm{OH})_{4}\right][58]$, $\left[\mathrm{C}_{2} \mathrm{H}_{10} \mathrm{~N}_{2}\right]\left[\mathrm{B}_{5} \mathrm{O}_{8}(\mathrm{OH})\right][81],\left[\mathrm{NH}_{4}\right]\left[\mathrm{B}_{5} \mathrm{O}_{6}(\mathrm{OH})_{4}\right] \cdot 2 \mathrm{H}_{2} \mathrm{O}$ [31], $\mathrm{Rb}\left[\mathrm{B}_{5} \mathrm{O}_{6}(\mathrm{OH})_{4}\right] 2 \mathrm{H}_{2} \mathrm{O}$ [31] and $\left[\mathrm{Zn}\left(\mathrm{B}_{5} \mathrm{O}_{7}\right)(\mathrm{OH})_{3}\left(\mathrm{C}_{10} \mathrm{H}_{24} \mathrm{~N}_{4}\right)\right]$ [108]. All of these compounds display second-order NLO behaviour and 
with $\left[\mathrm{C}_{2} \mathrm{H}_{10} \mathrm{~N}_{2}\right]\left[\mathrm{B}_{5} \mathrm{O}_{8}(\mathrm{OH})\right][81]$ and $\left[\mathrm{C}_{6} \mathrm{H}_{13} \mathrm{~N}_{2}\right]\left[\mathrm{B}_{5} \mathrm{O}_{6}(\mathrm{OH})_{4}\right]$ [58] having a second harmonic generation (SHG) efficiency of 1.2- and 0.9-times, of that of $\mathrm{KH}_{2} \mathrm{PO}_{4}$, respectively.

The templated pentaborate $\left[\mathrm{Ni}(\mathrm{en})_{2}(\mathrm{pip})\right]\left[\mathrm{B}_{5} \mathrm{O}_{6}(\mathrm{OH})_{4}\right]_{2}$ has been shown to have ferroelectric properties [69].

${ }^{11} \mathrm{~B}$ NMR data for polyborate anions have been reported for a limited number of salts $[18,19,25,39,41,43,45,48,52,56,59,75,93,95,96]$ but such data is not always meaningful since the salts are usually only soluble in $\mathrm{H}_{2} \mathrm{O}$ and dissolution of polyborate anions in $\mathrm{H}_{2} \mathrm{O}$ yields an equilibrium distribution of various borate species. Nevertheless, reasonably concentrated aqueous solutions of pentaborate(1-) salts generally show peaks at $+1,+13$ and +18 ppm ( 20:30:50 ratio) [43] and these are attributed to the tetrahedral centre of the pentaborate anion, the triborate(1-) anion, and an exchanging $\mathrm{B}(\mathrm{OH})_{3} /\left[\mathrm{B}(\mathrm{OH})_{4}\right]^{-}$monoborate species [109]. ${ }^{11} \mathrm{~B}$ NMR spectra of very dilute pentaborate(1-) solutions show only one peak at $+16.1 \mathrm{ppm}$, corresponding to equilibrium monoborate species, since under these conditions polyborate formation is suppressed. The observed chemical shift $\left(\delta_{\text {obs }}\right)$ is dependent upon the relative proportions of trigonal and tetrahedral boron centres in solution and the (total boron)/charge ratio, $\left(\mathrm{B}^{-} / 1\right)$, can be calculated for polyborates using $\left(\mathrm{B}^{-} / 1\right)=-17.0 /\left(\delta_{\mathrm{obs}}-\right.$ 19.5) [45].

Most researchers report vibrational (Raman, or more commonly, IR) spectroscopic data for new compounds they have prepared. Boron-oxygen bonds are polar and strong bands are usually observed below $1450 \mathrm{~cm}^{-1}$. Spectra are usually interpreted with reference to an analysis performed by $\mathrm{Li}$ and co-workers [110] who have tabulated the expected vibrational modes of polyborate anions. Spectra can be broken down into general diagnostic regions e.g. $1450-1300 \mathrm{~cm}^{-1}$, asymmetric stretching $\mathrm{B}_{(3)} \mathrm{O} ; 1150-1000 \mathrm{~cm}^{-1}$, asymmetric stretching $\mathrm{B}_{(4)}-\mathrm{O} ; 960-890 \mathrm{~cm}^{-1}$, symmetric stretching $\mathrm{B}_{(3)}-\mathrm{O} ; 890-740 \mathrm{~cm}^{-1}$, symmetric stretching $\mathrm{B}_{(4)}-\mathrm{O} ; 750-620 \mathrm{~cm}^{-1}$, out of plane bending $\mathrm{B}_{(3)}-\mathrm{O} ; 650$ $530 \mathrm{~cm}^{-1}$, pulse vibration (Raman); $<590 \mathrm{~cm}^{-1}$, bending of $\mathrm{B}_{(3)}-\mathrm{O}$ and $\mathrm{B}_{(4)}-\mathrm{O}$. This guide is useful although spectra are complicated since there are often many peaks in each region and regions also overlap. Despite this, some apparently diagnostic frequencies have been identified. Thus, $\left[\mathrm{NH}_{4}\right]\left[\mathrm{Co}\left(\mathrm{NH}_{3}\right)_{5}\left(\mathrm{H}_{2} \mathrm{O}\right)\right]\left[\mathrm{B}_{4} \mathrm{O}_{5}(\mathrm{OH})_{4}\right] \cdot 6 \mathrm{H}_{2} \mathrm{O}[27]$ and $\left[\mathrm{Cu}(\mathrm{en})_{2}\left\{\mathrm{~B}(\mathrm{OH})_{3}\right\}\right]\left[\mathrm{B}_{4} \mathrm{O}_{5}(\mathrm{OH})_{4}\right] \cdot \mathrm{B}(\mathrm{OH})_{3}[28]$ 
show a pulse vibration in the Raman spectra for the isolated tetraborate(2-) anion at $575 \mathrm{~cm}^{-1}$, and $[\mathrm{NMC}]\left[\mathrm{B}_{5} \mathrm{O}_{6}(\mathrm{OH})_{5}\right]^{-}$show a characteristic band at $\sim 925 \mathrm{~cm}^{-1}$ in IR spectra [56].

$\left[\mathrm{H}_{2} \mathrm{~N}\left(\mathrm{CH}_{2} \mathrm{CH}_{2}\right)_{2} \mathrm{NH}_{2}\right]\left[\mathrm{B}_{3} \mathrm{O}_{3}(\mathrm{OH})_{4}\right]$ shows IR BO bands at centred at 1414, 1305, 985, and $862 \mathrm{~cm}^{-1}$ [18]. [cyclo- $\left.\mathrm{C}_{6} \mathrm{H}_{11} \mathrm{NH}_{3}\right]_{2}\left[\mathrm{~B}_{7} \mathrm{O}_{9}(\mathrm{OH})_{5}\right] \cdot 3 \mathrm{H}_{2} \mathrm{O} \cdot \mathrm{B}(\mathrm{OH})_{3}[95]$ and [cyclo$\left.\mathrm{C}_{7} \mathrm{H}_{13} \mathrm{NH}_{3}\right]_{2}\left[\mathrm{~B}_{7} \mathrm{O}_{9}(\mathrm{OH})_{5}\right] \cdot 2 \mathrm{H}_{2} \mathrm{O} \cdot 2 \mathrm{~B}(\mathrm{OH})_{3}[95]$, which contain the ' $\mathrm{O}^{+}$' heptaborate(2-) isomer, both show strong IR bands at 905 and $863 \mathrm{~cm}^{-1}$. An IR band at $943 \mathrm{~cm}^{-1}$ has been tentatively assigned to a symmetric stretching $\mathrm{B}_{(3)}-\mathrm{O}$ mode of the nonaborate(3-) anion [48]. The totally symmetric Raman stretching shifts for polyborates in aqueous solution have been investigated by DFT theory (B3LYP/aug-cc-pVDZ) level and compared with experimental Raman spectra obtained at room temperature; at least six borates $\left(\mathrm{B}(\mathrm{OH})_{3},\left[\mathrm{~B}(\mathrm{OH})_{4}\right]^{-},\left[\mathrm{B}_{3} \mathrm{O}_{3}(\mathrm{OH})_{4}\right]^{-},\left[\mathrm{B}_{3} \mathrm{O}_{3}(\mathrm{OH})_{5}\right]^{2-},\left[\mathrm{B}_{4} \mathrm{O}_{5}(\mathrm{OH})_{4}\right]^{2-}\right.$ and $\left.\left[\mathrm{B}_{5} \mathrm{O}_{6}(\mathrm{OH})_{4}\right]^{-}\right)$were identified [111].

Polyborate anions have been geometry optimised (B3LYP/6-311++G $(d, p)$ level) in the gasphase, and their structures have been examined using the QTAIM approach [112]; the triborate(1-), rather than the pentaborate(1-) anion which is commonly observed in synthetic polyborate salts, has the lowest relative energy per boron atom. Conformational analysis of the $\mathrm{O}-\mathrm{H}$ bonds in the hexaborate(2-) (Figure 8) and heptaborate(2-) (Figure 9b) have been undertaken by DFT calculations which show that intramolecular H-bonds stabilize the ions [113]. DFT calculations have been used to model H-bond interactions found in solid-state pentaborate(1-) structures and it is believed that these interactions dominate solid-state energetics (Section 3.4) [45]. Structural and charge density distribution calculations (B3LYP/6-31G** level) using the QTAIM approach have been carried out on single crystal XRD data for [trans-1,4-bis(3-aminopropyl)piperazinium(2+)][B $\left.\mathrm{B}_{5} \mathrm{O}_{6}(\mathrm{OH})_{4}\right]_{2}$ and it was concluded that the $\mathrm{O}-\mathrm{H}^{\cdots} \mathrm{O}$ and $\mathrm{N}-\mathrm{H} \cdots \mathrm{O}$ H-bonds play a key role in the solid-state energetics [114]. 


\subsection{Summary}

Synthetic isolated and polymeric hydrated polyborates with either transition-metal complex cations or organic non-metal cations are a rapidly expanding area of solid-state chemistry with many new structural types emerging. However, synthetic methods are generally non-targeted and a challenge for synthetic chemists is to find rational high yield ways to prepare specific compounds. Polyborate salts have found applications as fire retardant polymer additives, preservatives in wood composites, and second-order NLO materials. Properties (wide band-gap semiconductor, photo-luminescent, ferroelectric, fluorescent) exhibited by some of the salts described in this review would indicate that potentially they may also have other useful applications.

\section{References}

[1] J.B. Farmer, Adv. Inorg. Radiochem.25 (1982) 187-237.

[2] G. Heller, Topics in Current Chemistry 131 (1986) 39-98.

[3] P. Becker, Adv. Materials 10 (1998) 979-992.

[4] C.L. Christ, J.R. Clark, Phys. Chem. Minerals 2 (1977) 59-87.

[5] P.C. Burns, J.D. Grice, F.C. Hawthorne, Can. Mineral. 33 (1995) 1131-1151.

[6] P.C. Burns, Can. Mineral. 33 (1995) 1167-1176.

[7] J.D. Grice, P.C. Burns, F.C. Hawthorne, Can. Mineral. 37 (1999) 731-762.

[8] M. Schindler and F.C. Hawthorne, Can. Mineral. 39 (2001) 1225-1242.

[9] M. Touboul, N. Penin, G. Nowogrocki, Solid State Sci. 5 (2003) 1327-1342.

[10] D.M. Schubert, R.A. Smith, M.Z. Visi, Glass Technol. 44 (2003) 63-70.

[11] D.M. Schubert, C.B. Knobler, Phys. Chem. Glasses: Eur. J. Glass Sci. Technol. B 50 (2009) 7178. 
[12] D.M. Schubert, Structure and Bonding 105 (2003) 1-40.

[13] E.L. Belokoneva, Crystallography Reviews 11 (2005) 151-198.

[14] D.M. Schubert, Kirk-Othmer Encyclopedia of Chemical Technology ( $5^{\text {th }}$ Ed.), J. Wiley and Sons, NY, (2011) 1-68.

[15] R.W. Sprague in 'Mellor's Comprehensive Treatise on Inorganic and Theoretical Chemistry', Longman Group, Volume 5 (Boron, Supplement 1, Part A, B-O Compounds) (1980) Section A6, 224333.

[16] Q. Li, F. Xue, T.C.W. Mak, Inorg. Chem. 38 (1999) 4142-4145.

[17] D.M. Schubert, M.Z. Visi, C.B. Knobler, Inorg. Chem. 47 (2008) 2017-2023.

[18] M.A. Beckett, P.N. Horton, M.B. Hursthouse, J.L.Timmis, RSC Advances 3 (2013) 1518515191.

[19] M.A. Altahan, M.A. Beckett, S.J. Coles, P.N. Horton, Phosphorus, Sulfur, and Silicon (2016) in press.

[20] G.-Z. Liu, S.-T. Zheng, G.-Y. Yang, Inorg. Chem. Commun. 10 (2007) 84-87.

[21] D.M. Schubert, F. Alam, M.Z. Visi, C.B. Knobler, Chem. Mater. 15 (2003) 866-871.

[22] G.-M Wang, Y.-Q Sun, S.-T. Zheng, G.-Y. Yang, Z. Anorg. Allg. Chem. 632 (2006) 1586-1590.

[23] C.-Y. Pan, G.-M. Wang, S.-T. Zheng, G.-Y. Yang, Acta Cryst E63 (2007) o1207-1209.

[24] G.-M. Wang, Y.-Q. Sun, G.-Y. Yang, J. Solid State Chem. 177 (2004) 4648-4654.

[25] M.A. Beckett, P.N. Horton, S.J. Coles, D.W. Martin, Inorg. Chem. 50 (2011) 12215-12218.

[26] L. Zheng, J. Zhang, Z. Liu, Chin. J. Chem. 27 (2009) 494-500.

[27] D. Lin, X. You, L. Zhu, Chin. J. Chem. 29 (2011) 468-472.

[28] D. Lin, X. You, L. Zhu, Chin. J. Chem. 29 (2011) 463-467. 
[29] (a) G.J. Gainsford, T. Kemmitt, C. Higham, Acta Cryst. E64 (2008) i24-i25; (b) H.A. Levy, G.C. Lisensky, Acta Cryst. B34 (1978) 3502-3510.

[30] P. Zhao, L. Cheng, G.-Y. Yang, Inorg. Chem. Commun. 20 (2012) 138-141.

[31] P. Becker, P. Held, L. Bohaty, Cryst. Res. Technol. 35 (2000) 1251-1262.

[32] Z. Yang, S. Yang, G. Li, J. Liu, Acta Physico-Chemica Sinica, 23 (2007) 284-288.

[33] R. A. Baber, J.P.H. Charmant, N.C. Norman, A.G. Orpen, J. Rossi, Acta Cryst. E60 (2004) o1086-o1088.

[34] P. Li, Z. Liu, Chin. J. Chem. 27 (2009) 2183-2189.

[35] P. Li, L.-Q. Li, H.-S. Huang, Z.-H. Liu, J. Clust. Sci. 25 (2014) 893-903.

[36] H.-X. Zhang, S.-T. Zheng, G.-Y. Yang, Acta Cryst. C60 (2004) o545-o546.

[37] J. Liang, Y.-G. Wang, Y.-X. Wang, F.-H. Liao, J.-H. Lin, J. Solid State Chem. 200 (2013) 99104.

[38] C.-Y. Pan, G.-M. Wang, S.-T. Zheng, G.-Y. Yang, Acta Cryst. E63 (2007) o840-o842.

[39] M.A. Beckett, P.N. Horton, M.B. Hursthouse, J.L. Timmis, K.S. Varma, Collect. Czech. Chem. Commun.75 (2010) 971-980.

[40] M.Z. Visi, C.B. Knobler, J.J. Owen, M.I. Khan, D.M. Schubert, Crystal Growth \& Design 6 (2006) 538-545.

[41] M.A. Beckett, P.N. Horton, M.B. Hursthouse, J.L. Timmis, K.S. Varma, Dalton Trans. 41 (2012) 4396-4403.

[42] H. Li, G.-M. Wang, S.-Y. Xue, Q. Liang, Acta Cryst. E64 (2008) m1269-m1270.

[43] M.A. Beckett, P.N. Horton, M.B. Hursthouse, D.A. Knox, J.L. Timmis, Dalton Trans. 39 (2010) 3944-3951.

[44] D.M. Schubert, M.Z. Visi, C.B. Knobler, Inorg. Chem. 47 (2008) 2017-2023. 
[45] M.A. Beckett, S.J. Coles, R.A. Davies, P.N. Horton, C.L. Jones, Dalton Trans. 44 (2015) $7032-$ 7040.

[46] W.-H. Han, L.-L. Dang, W.-J. Zhang, Z. Kristallogr.222 (2007) 403-404.

[47] H.-X. Yang, W.-J. Zhang, X.-L. Liu, Z.-H. Liu, Acta Cryst. E62 (2006) o4877-o4879.

[48] M.A. Beckett, P.N. Horton, M.B. Hursthouse, J.L. Timmis, Polyhedron 77 (2014) 96-102.

[49] T.G. Parker, D. Pubbi, A. Beehler, T.E. Albrecht-Schmitt, Acta Cryst. E70 (2014) o171-o172.

[50] Y. Liu, H. He, B.-F. Yang, Q. Zhang, G.-Y. Yang, J. Clust. Sci. 26 (2015) in press; doi $10.1007 / \mathrm{s} 10876-015-0845-2$

[51] W.-J. Zhang, Z.-H. Liu, Z. Kristallogr.221 (2006) 189-190.

[52] M.A. Beckett, C.C. Bland, P.N. Horton, M.B. Hursthouse, K.S. Varma, J. Organomet. Chem. 692 (2007) 2832-2838.

[53] C.Y. Pan, L.-J. Zhong, J. Lu, D.-G. Li, F.-H. Zhao, H.-M. Yang, Z. Anorg. Allg. Chem. 640 (2014) 352-356.

[54] Y. Yang, D. Fu, G. Li, Y. Zhang, Z. Anorg. Allg. Chem. 639 (2013) 722-727.

[55] V.R. Hathwar, A.K. Paul, S. Natarajan, T.N.G. Row, J. Phys. Chem. A 115 (2011) 12818-12825.

[56] M.A. Beckett, P.N. Horton, S.J. Coles, D.A. Kose, A.-M. Kreuziger, Polyhedron 38 (2012) 157161.

[57] G. Haung, R. Pan, H. He, B.-F. Yang, G.-Y. Yang, J. Cluster Sci. 2015 in press; doi: 10.1007/s10876-015-0900-z.

[58] H.-X. Liu, Y.-X. Liang, X. Jiang, J. Solid State Chem. 181 (2008) 3243-3247.

[59] M.A. Beckett, P.N. Horton, M.B. Hursthouse, J.L. Timmis, K.S. Varma, Inorg. Chim. Acta.383 (2012) 199-203. 
[60] Y. Yang, Y. Wang, J. Zhu, R.-B. Liu, J. Xu, C.-G. Meng, Z. Anorg. Allg. Chem. 637 (2011) 735740.

[61] L. Zhao, P. Li, B. Cao, Acta Cryst. E65 (2009) m368-m368.

[62] M.A. Altahan, M.A. Beckett, S.J. Coles, P.N. Horton, Inorg. Chem. 54 (2015) 412-414.

[63] Q. Meng, G.-M. Wang, H. He, B.-F. Yang, G.-Y. Yang, J. Cluster Sci. 25 (2014) 1295-1305

[64] G.-M. Wang, Y.-Q. Sun, G.-Y. Yang, J. Solid State Chem.179 (2006) 1545-1553.

[65] X .You, L. Zhu, J. Sun, Chin. J. Chem. 28 (2010) 2174-2178.

[66] Y. Yang, Y. Wang, J. Zhu, R.-B. Liu, J. Xu, C.-G. Meng, Inorg Chim Acta, 376 (2011) 401-407.

[67] Y. Yang, D. Fu, Y. Zhang, C. Meng, Z. Anorg. Allg. Chem. 640 (2014) 1443-1448.

[68] H.-X. Zhang, S.-T. Zheng, G.-Y. Yang, Acta Cryst. C60 (2004) m241-m243.

[69] C.-Y. Pan, S. Hu, D.-G. Li, P. Ouyang, F.-H. Zhao, Y.-Y. Zheng, Dalton Trans. 39 (2010) 57725773.

[70] Z.-H. Liu, J.-J. Zhang, W.-J. Zhang, Inorg. Chim. Acta 359 (2006) 519-524.

[71] X. Liu, F. Zhang, X.-H. Yin, Chemical Research and Application 22 (2010) 12.

[72] G.-M. Wang, Y-Q. Sun, G.-Y. Yang, J. Solid State Chem. 178 (2005) 729-735.

[73] S.-L. Wu, H.-X. Liu, X. Jiang, Z.-D. Shao, Y.-X. Liang, Acta Cryst. C65 (2009) m308-m310.

[74] N. Penin, L. Seguin, B. Gerand, M. Touboul, G. Nowagrocki, J Alloys and Compounds 334 (2002) 97-109.

[75] C.L. Jones, M.A. Beckett, S.J. Coles, R.A. Davies, P.N. Horton, Phosphorus, Sulfur and Silicon, (2016) in press.

[76] M. Wiebcke, C.C. Freyhardt, J. Felsche, G. Englehardt, Z. Naturforsch. 48b (1993) 978-985. 
[77] C.C. Freyhardt, M. Wiebcke, J. Felsche, G. Englehardt, J. Incl. Phenom. and Mol. Rec. in Chem. 18 (1994) 161-175.

[78] G.-M. Wang, Y.-Q. Sun, G.-Y. Yang, J. Solid State Chem. 178 (2005) 729-735.

[79] [G.-M. Wang, J.-H. Li, Z.-X. Li, P. Wang, H. Li, Z. Anorg. Allg. Chem. 634 (2008) 1192-1196.

[80] G.-M. Wang, C.-Y. Pan, S.-T. Zheng, G.-Y. Yang, Acta Cryst. E63 (2007) o1104-o1105

[81] S. Yang, G. Li, S. Tian, F. Liao, J. Lin, Crystal Growth \& Design 7 (2007) 1246-1250.

[82] G.-M. Wang, C.-Y. Pan, S.-T. Zheng, G.-Y. Yang, Acta Cryst. E63 (2007) o1101-o1103.

[83] G.-M. Wang, Y.-Q. Sun, G.-Y. Yang, J. Solid State Chem. 177 (2004) 4648-4654.

[84] X. Chen, Y. Zhao, X. Chang, J. Zuo, H. Zang, W. Xiao, J. Solid State Chem. 179 (2006) 39113918.

[85] D.M. Schubert, C.B. Knobler, M.Z. Visi, Main Group Chem. 11 (2012) 69-88.

[86] M.C. Etter, Acc. Chem. Res. 23 (1990) 120-126.

[87] N. Jemai, M. Rzaigui, S. Akriche, J. Clust. Sci. 26 (2015) in press; doi 10.1007/s10876-0150905-7).

[88] S.-M. Lan, W.-J. Di, Z.-D. Shao, Y.-X. Liang, Acta Crtstallogr. C67 (2011) m338-m341

[89] Z.-H. Liu, L.-Q. Li, W.-J. Zhang, Inorg. Chem. 45 (2006) 1430-1432.

[90] Z.-H. Liu, L.-Q. Li, Crystal Growth \& Design 6 (2006) 1247-1249.

[91] P. Li, L.-Q. Li, H.-S. Huang, Z.-H. Liu, J. Clust. Sci. 25 (2014) 893-903.

[92] C.-Y. Pan, G.-M. Wang, S.-T. Zheng, G.-Y. Yang, Z. Anorg. Allg. Chem. 633 (2007) 336-340.

[93] M.A. Beckett, P.N. Horton, S.J. Coles, D.W. Martin, Inorg. Chem. 50 (2011) 12215-12218.

[94] D.M. Schubert. M.Z. Visi, S. Khan, C.B. Knobler, Inorg. Chem. 47 (2008) 4740-4745. 
[95] M.A. Beckett, P.N. Horton, M.B. Hursthouse, J.L. Timmis, K.S. Varma, Dalton Trans. 41 (2012) 4396-4403.

[96] M.A. Altahan, M.A. Beckett, S.J. Coles, P.N. Horton, Inorg. Chem. Commun. 59 (2015) 95

[97] H.H.-Y. Sung, M. Wu, I.D. Williams, Inorg. Chem. Commun. 3 (2000) 401-404.

[98] S. Yang, G. Li, S. Tian, F. Liao, M. Xiong, J. Lin, J. Solid State Chem. 180 (2007) 2225-2232.

[99] C.-Y. Pan, G.-M. Wang, S.-T. Zheng, G.-Y. Yang, J. Solid State Chem. 280 (2007) 1553-1558.

[100] D.M. Schubert, M.Z. Visi, C.B. Knobler, Inorg. Chem. 39 (2000) 2250-2251.

[101] H.-X. Zhang, J. Zhang, S.-T. Zheng, G.-Y. Yang, Inorg. Chem. Commun. 7 (2004) 781-783.

[102] C. Rong, J. Jiang, Q.-L. Li, Chin. J. Inorg. Chem. 28 (2012) 2217-2222.

[103] M. Yang, Z. Zhang, H. Ding, J.-Y. Li, Chem. Res. Chinese Universities 26 (2010) 335-338.

[104] L. Wei, B.-F. Yang, H. He, G.-Y. Yang, J. Clust. Sci. 25 (2014) 617-626.

[105] J.E. Anderson, R.S. Bubnova, S.K. Filatov, V.L. Ugolkov, S.N. Britvin, Glass Physics and Chemistry 35 (2009) 191-198.

[106] P.T. Corbett, J. Leclaire, L. Vial, K.R. West, J.-L. Wietor, J.K.M. Sanders, S. Otto, Chem. Rev. 106 (2006) 3652-3711.

[107] J.L.Anderson, E.M. Eyring, M.P. Whittaker, J. Phys Chem. 68 (1964) 1128-1132.

[108] A.K. Paul, K. Sachidananda, S. Natarajan, Crystal Growth \& Design 10 (2010) 456-464.

[109] C.G. Salentine, Inorg. Chem. 22 (1983) 3920-3924.

[110] J. Li, S. Xia, S. Goa, Spectrochem Acta 51A (1995) 519-532.

[111] Y. Zhou, C. Fang, Y. Fang, F. Zhu, Spectrochemica Acta A83 (2011) 82-87.

[112] M.A. Beckett, R. A. Davies, C.D. Thomas, Compt. and Theo. Chem. 1044 (2014) 74-79.

[113] R.A. Davies, M.A. Beckett, C.L. Jones Phosphorus, Sulfur and Silicon, (2016) in press; doi .... 
[114] C.G. Salentine, Inorg. Chem. 26 (1987) 128-132.

[115] W. Luo, Y. Wang, T. Wen, H. Zhang, X. Lin, Y. Wang, F. Liao, J. Lin, J. Mol. Struct. 1048 (2013) 1-5. 
Table 1. Crystallographically determined (XRD) structures containing the pentaborate(1-), $\left[\mathrm{B}_{5} \mathrm{O}_{6}(\mathrm{OH})_{4}\right]^{-}$, anion (See Figure 5a). In the formula below 5 is used to represent $\left[\mathrm{B}_{5} \mathrm{O}_{6}(\mathrm{OH})_{4}\right]^{-}$.

\begin{tabular}{|c|c|c|c|}
\hline Formula & Cation comments & Interstitial & Reference \\
\hline \multicolumn{4}{|l|}{ Non-metal cations } \\
\hline$\left[\mathrm{NH}_{4}\right] 5 \cdot 2 \mathrm{H}_{2} \mathrm{O}$ & ammonium & $2 \mathrm{H}_{2} \mathrm{O}$ & [31] \\
\hline$\left[\mathrm{Et}_{3} \mathrm{NH}\right] \mathbf{5}$ & triethylammonium & & [32] \\
\hline$\left[\mathrm{Me}_{2} \mathrm{NH}_{2}\right] 5$ & dimethylammonium & & [33] \\
\hline$\left[\mathrm{Me}_{2} \mathrm{NH}_{2}\right] 5 \cdot \mathrm{DMF}$ & dimethylammonium & $\mathrm{HCONMe}_{2}$ & {$[34]$} \\
\hline$\left[\mathrm{Me}_{3} \mathrm{NH}\right] \mathbf{5}$ & trimethylammonium & & {$[35]$} \\
\hline$\left[\mathrm{Me}_{4} \mathrm{~N}\right] 5 \cdot 0.25 \mathrm{H}_{2} \mathrm{O}$ & tetramethylammonium & $0.25 \mathrm{H}_{2} \mathrm{O}$ & [36] \\
\hline$\left[\mathrm{Me}_{3}{ }^{\mathrm{i}} \mathrm{PrN}\right] 5$ & $\begin{array}{l}\text { isopropyltrimethylammon } \\
\text { ium }\end{array}$ & & [37] \\
\hline$\left[\mathrm{H}_{3} \mathrm{NBu}\right] 5$ & butylammonium & & [38] \\
\hline$\left[\mathrm{C}_{6} \mathrm{H}_{5} \mathrm{CH}_{2} \mathrm{NH}_{3}\right] 5$ & benzylammonium & & [39] \\
\hline$\left[\mathrm{H}_{3} \mathrm{~N}\left(\mathrm{CH}_{2}\right)_{5} \mathrm{NH}_{3}\right] \mathbf{5}_{2}$ & $\alpha, \omega$-alkyldiammonium & & {$[40]$} \\
\hline$\left[\mathrm{H}_{3} \mathrm{~N}\left(\mathrm{CH}_{2}\right)_{6} \mathrm{NH}_{3}\right] \mathbf{5}_{2}$ & $\alpha, \omega$-alkyldiammonium & & [40] \\
\hline$\left[\mathrm{H}_{3} \mathrm{~N}\left(\mathrm{CH}_{2}\right)_{8} \mathrm{NH}_{3}\right] \mathbf{5}_{2}$ & $\alpha, \omega$-alkyldiammonium & & [40] \\
\hline$\left[\mathrm{H}_{3} \mathrm{~N}\left(\mathrm{CH}_{2}\right)_{9} \mathrm{NH}_{3}\right] \mathbf{5}_{2}$ & $\alpha, \omega-$ alkyldiammonium & & {$[40]$} \\
\hline$\left[\mathrm{H}_{3} \mathrm{~N}\left(\mathrm{CH}_{2}\right)_{10} \mathrm{NH}_{3}\right] \mathbf{5}_{2}$ & $\alpha, \omega$-alkyldiammonium & & [40] \\
\hline$\left[\mathrm{H}_{3} \mathrm{~N}\left(\mathrm{CH}_{2}\right)_{11} \mathrm{NH}_{3}\right] \mathbf{5}_{2}$ & $\alpha, \omega-$ alkyldiammonium & & [40] \\
\hline$\left[\mathrm{H}_{3} \mathrm{~N}\left(\mathrm{CH}_{2}\right)_{12} \mathrm{NH}_{3}\right] \mathbf{5}_{2} \cdot 4 \mathrm{H}_{2} \mathrm{O}$ & $\alpha, \omega$-alkyldiammonium & $4 \mathrm{H}_{2} \mathrm{O}$ & {$[40]$} \\
\hline$\left[\mathrm{C}_{3} \mathrm{H}_{5} \mathrm{NH}_{3}\right] \mathbf{5}$ & cyclo-propylammonium & & [41] \\
\hline$\left[\mathrm{C}_{5} \mathrm{H}_{9} \mathrm{NH}_{3}\right] \mathbf{5}$ & cyclo-pentylammonium & & [41] \\
\hline$\left[\mathrm{C}_{6} \mathrm{H}_{11} \mathrm{NH}_{3}\right] \mathbf{5}$ & cyclo-hexylammonium & & [115] \\
\hline$\left[\mathrm{C}_{6} \mathrm{H}_{11} \mathrm{NMe}_{3}\right] \mathbf{5}$ & $\begin{array}{l}\text { substituted cyclo- } \\
\text { hexylammonium }\end{array}$ & & [41] \\
\hline$\left[\mathrm{C}_{6} \mathrm{H}_{11} \mathrm{NHMe}_{2}\right] \mathbf{5}$ & $\begin{array}{l}N, N \text {-disubstituted cyclo- } \\
\text { hexylammonium }\end{array}$ & & {$[42]$} \\
\hline$\left[\mathrm{NH}_{3} \mathrm{CMe}\left(\mathrm{CH}_{2} \mathrm{OH}\right)_{2}\right] \mathbf{5} \cdot 0.16 \mathrm{H}_{2} \mathrm{O}$ & aliphatic ammonium & $0.16 \mathrm{H}_{2} \mathrm{O}$ & [43] \\
\hline$\left[\mathrm{Me}_{3} \mathrm{NCMe}_{2}\left(\mathrm{CH}_{2} \mathrm{OH}\right)\right] \mathbf{5}$ & aliphatic ammonium & & [43] \\
\hline$\left[\mathrm{HOCH}_{2} \mathrm{CH}_{2} \mathrm{NH}_{3}\right] \mathbf{5} \cdot \mathrm{H}_{2} \mathrm{O}$ & aliphatic ammonium & $\mathrm{H}_{2} \mathrm{O}$ & [44] \\
\hline$\left[\mathrm{C}_{4} \mathrm{H}_{8} \mathrm{NH}_{2}\right] \mathbf{5}$ & pyrrolidinium & & [45] \\
\hline$\left[\mathrm{C}_{4} \mathrm{H}_{8} \mathrm{NMe}_{2}\right] \mathbf{5}$ & $\begin{array}{l}N, N \text {-disubstituted } \\
\text { pyrrolidinium }\end{array}$ & & {$[45]$} \\
\hline$\left[\mathrm{C}_{4} \mathrm{H}_{8} \mathrm{NMeH}\right] \mathbf{5} \cdot 1 / 2 \mathrm{CH}_{3} \mathrm{COCH}_{3}$ & $\begin{array}{l}N \text {-substituted } \\
\text { pyrrolidinium }\end{array}$ & $0.5 \mathrm{CH}_{3} \mathrm{COCH}_{3}$ & [45] \\
\hline$\left[2-\left(\mathrm{HOCH}_{2}\right) \mathrm{C}_{4} \mathrm{H}_{7} \mathrm{NH}_{2}\right] \mathbf{5}$ & substituted pyrrolidinium & & [45] \\
\hline $\begin{array}{l}{[2-} \\
\left.\left(\mathrm{HOCH}_{2} \mathrm{CH}_{2}\right) \mathrm{C}_{4} \mathrm{H}_{7} \mathrm{NMeH}\right] \mathbf{5} \cdot 0.5 \mathrm{H}_{2} \mathrm{O}\end{array}$ & substituted pyrrolidinium & $0.5 \mathrm{H}_{2} \mathrm{O}$ & {$[75]$} \\
\hline$\left[\left(\mathrm{CH}_{2}\right)_{4} \mathrm{NH}\left(\mathrm{CH}_{2} \mathrm{CH}_{2} \mathrm{OH}\right)\right] \mathbf{5}$ & substituted pyrrolidinium & & [43] \\
\hline$\left[\mathrm{C}_{3} \mathrm{H}_{5} \mathrm{~N}_{2}\right] 5$ & imidazolium & & [46] \\
\hline$\left[2-\mathrm{MeC}_{3} \mathrm{H}_{4} \mathrm{~N}_{2}\right] \mathbf{5}$ & substituted imidazolium & & $\begin{array}{l}{[43]} \\
{[47]}\end{array}$ \\
\hline$\left[1,2-\mathrm{Me}_{2} \mathrm{C}_{3} \mathrm{H}_{3} \mathrm{~N}_{2}\right] 5 \cdot \mathrm{H}_{2} \mathrm{O}$ & substituted imidazolium & $\mathrm{H}_{2} \mathrm{O}$ & [48] \\
\hline$\left[1-\mathrm{Et}-3-\mathrm{MeC}_{3} \mathrm{H}_{3} \mathrm{~N}_{2}\right] \mathbf{5}$ & substituted imidazolium & & [49] \\
\hline
\end{tabular}




\begin{tabular}{|c|c|c|c|}
\hline$\left[1,2,3-\mathrm{Me}_{3} \mathrm{C}_{3} \mathrm{H}_{2} \mathrm{~N}_{2}\right] \mathbf{5}$ & substituted imidazolium & & {$[48]$} \\
\hline$\left[2-\mathrm{EtC}_{3} \mathrm{H}_{4} \mathrm{~N}_{2}\right] \mathbf{5}$ & substituted imidazolium & & [48] \\
\hline [2-Et-4- $\left.\mathrm{MeC}_{3} \mathrm{H}_{3} \mathrm{~N}_{2}\right] \mathbf{5}$ & substituted imidazolium & & [48] \\
\hline$\left[2-{ }^{\mathrm{i}} \mathrm{PrC}_{3} \mathrm{H}_{4} \mathrm{~N}_{2}\right] \mathbf{5}$ & substituted imidazolium & & [48] \\
\hline$\left[2-\mathrm{MeC}_{3} \mathrm{H}_{6} \mathrm{~N}_{2}\right] \mathbf{5}$ & substituted imidazolinium & & [48] \\
\hline$\left[\mathrm{C}_{4} \mathrm{H}_{11} \mathrm{~N}_{2} \mathrm{O}\right]\left[\mathrm{C}_{4} \mathrm{H}_{9} \mathrm{~N}_{2}\right] \mathbf{5}_{2}$ & $\begin{array}{l}\text { substituted } \\
\text { dihydroimidazolium and } \\
\text { 2-(N-methylacetamido) } \\
\text { ethaninium cations }\end{array}$ & & [50] \\
\hline$[\mathrm{pyH}] \mathbf{5 . 1 / 2 p y}$ & py $=$ pyridine & $1 / 2$ py & [51] \\
\hline [4-МеруH,4-Меру]5 & substituted pyridinium & 4-Mepy & [52] \\
\hline$\left[\mathrm{C}_{9} \mathrm{H}_{14} \mathrm{~N}\right] 5$ & $N$-butylpyridinium & & [53] \\
\hline$\left[2-\left(\mathrm{HOCH}_{2} \mathrm{CH}_{2}\right) \mathrm{pyH}\right] \mathbf{5}$ & substituted pyridinium & & [43] \\
\hline$\left[\mathrm{C}_{10} \mathrm{H}_{9} \mathrm{~N}_{2}\right] 5 \cdot \mathrm{B}(\mathrm{OH})_{3} \cdot \mathrm{H}_{2} \mathrm{O}$ & $\begin{array}{l}{\left[\mathrm{C}_{10} \mathrm{H}_{9} \mathrm{~N}_{2}\right]=} \\
\text { monoprotonated } 4,4^{\prime}- \\
\text { bipyridine }\end{array}$ & $\begin{array}{l}\mathrm{B}(\mathrm{OH})_{3} \text { and } \\
\mathrm{H}_{2} \mathrm{O}\end{array}$ & [54] \\
\hline$\left[\mathrm{MeHN}\left(\mathrm{CH}_{2} \mathrm{CH}_{2}\right)_{2} \mathrm{NMe}\right] \mathbf{5}$ & $\begin{array}{l}\text { substituted } \\
\text { piperazine }(1+), \text { pip }\end{array}$ & & {$[18]$} \\
\hline$\left[\mathrm{Me}_{2} \mathrm{~N}\left(\mathrm{CH}_{2} \mathrm{CH}_{2}\right)_{2} \mathrm{NMe}_{2}\right] \mathbf{5}_{2}$ & substituted piperazine $(2+)$ & & [18] \\
\hline$\left[\mathrm{C}_{10} \mathrm{H}_{26} \mathrm{~N}_{4}\right] \mathbf{5}_{2}$ & $\begin{array}{l}\text { trans-1,2-bis(3- } \\
\text { ammoniumpropyl) } \\
\text { piperazine }(2+)\end{array}$ & & [55] \\
\hline$\left[\left(\mathrm{CH}_{2}\right)_{5} \mathrm{NH}\left(\mathrm{CH}_{2} \mathrm{CH}_{2} \mathrm{OH}\right)\right] \mathbf{5}$ & substituted piperidinium & & [43] \\
\hline$\left[\mathrm{O}\left(\mathrm{CH}_{2} \mathrm{CH}_{2}\right) \mathrm{NH}_{2}\right] \mathbf{5}$ & morpholinium & & [43] \\
\hline$\left[\mathrm{O}\left(\mathrm{CH}_{2} \mathrm{CH}_{2}\right)_{2} \mathrm{NMe}_{2}\right] \mathbf{5}$ & $\begin{array}{l}N, N \text {-disubstituted } \\
\text { morpholinium }\end{array}$ & & [43] \\
\hline$[\mathrm{HPS}] 5 \cdot \mathrm{B}(\mathrm{OH})_{3}$ & $\begin{array}{l}\text { PS }=1,8- \\
\text { bis(dimethylamino)- } \\
\text { naphthalene }\end{array}$ & $\mathrm{B}(\mathrm{OH})_{3}$ & {$[56]$} \\
\hline$\left[\mathrm{Me}_{3} \mathrm{NCH}_{2} \mathrm{CH}_{2} \mathrm{OH}\right] \mathbf{5}$ & choline & & [52] \\
\hline [MPD]5 & $\begin{array}{l}\text { MPD = 2-Me-1,4,5,6- } \\
\text { tetrahydropyrimidin-3- } \\
\text { ium }\end{array}$ & & [57] \\
\hline$\left[\mathrm{C}_{6} \mathrm{H}_{13} \mathrm{~N}_{2}\right] \mathbf{5}$ & $\begin{array}{l}\text { protonated cyclic amine } \\
\text { (DABCO) }\end{array}$ & & [58] \\
\hline$[\mathrm{HDBN}] \mathbf{5}$ & protonated cyclic amine & & [56] \\
\hline$\left[\mathrm{PPh}_{4}\right] 5 \cdot 1.5 \mathrm{H}_{2} \mathrm{O}$ & tetraphenylphosphonium & $1.5 \mathrm{H}_{2} \mathrm{O}$ & [59] \\
\hline \multicolumn{4}{|l|}{$\begin{array}{l}\text { Transition-metal cation } \\
\text { complexes }\end{array}$} \\
\hline$\left[\mathrm{Cd}(\mathrm{en})_{3}\right] \mathbf{5}_{2} \cdot 2 \mathrm{H}_{2} \mathrm{O}$ & en = ethylenediamine & $2 \mathrm{H}_{2} \mathrm{O}$ & [60] [50] \\
\hline$\left[\mathrm{Cd}(\operatorname{dien})_{2}\right] \mathbf{5}_{2}$ & dien $=$ diethylenetriamine & & [60] \\
\hline$\left[\mathrm{Co}(\mathrm{en})_{3}\right] \mathbf{5}_{2} \cdot 2 \mathrm{H}_{2} \mathrm{O}$ & en = ethylenediamine & $2 \mathrm{H}_{2} \mathrm{O}$ & [61] \\
\hline$\left[\mathrm{Co}(\mathrm{en})_{3}\right] \mathbf{5}\left[\mathrm{B}_{8} \mathrm{O}_{10}(\mathrm{OH})_{6}\right] \cdot 5 \mathrm{H}_{2} \mathrm{O}$ & en $=$ ethylenediamine & $\begin{array}{l}5 \mathrm{H}_{2} \mathrm{O} \text { with } \\
\text { octaborate(2-) } \\
\text { anion }\end{array}$ & [62] \\
\hline$\left[\mathrm{Co}(\text { dap })_{3}\right] \mathbf{5}_{2} \cdot \mathrm{H}_{2} \mathrm{O}$ & dap $=1,2$-diaminopropane & $\mathrm{H}_{2} \mathrm{O}$ & [63] \\
\hline$\left[\mathrm{Co}(\text { dien })_{2}\right] \mathbf{5}_{2}$ & dien $=$ diethylenetriamine & & [64] \\
\hline$\left[\mathrm{Co}_{2}(\text { teta })_{3}\right] \mathbf{5}_{4}$ & $\begin{array}{l}\text { teta }= \\
\text { triethylenetetraamine }\end{array}$ & & {$[64]$} \\
\hline$\left[\mathrm{Cu}\left(\mathrm{C}_{3} \mathrm{~N}_{2} \mathrm{H}_{4}\right)_{4}\right] \mathbf{5}_{2} \cdot \mathrm{C}$ & $\mathrm{C}_{3} \mathrm{~N}_{2} \mathrm{H}_{4}=$ imidazole & $\begin{array}{l}\mathrm{C}=\text { neutral } \\
\text { complex }\end{array}$ & [65] \\
\hline
\end{tabular}




\begin{tabular}{|c|c|c|c|}
\hline & & $\begin{array}{l}{\left[\mathrm{Cu}\left(\mathrm{CH}_{3} \mathrm{CO}\right)_{2}(\mathrm{C}\right.} \\
\left.\left.{ }_{3} \mathrm{~N}_{2} \mathrm{H}_{4}\right)\left(\mathrm{H}_{2} \mathrm{O}\right)_{2}\right]\end{array}$ & \\
\hline$\left[\mathrm{Cu}(\mathrm{en})_{2}\left(\mathrm{C}_{5} \mathrm{H}_{9} \mathrm{NO}\right)\right] \mathbf{5}_{2} \cdot \mathrm{C}_{5} \mathrm{H}_{9} \mathrm{NO}$ & $\begin{array}{l}\text { en }=\text { ethylenediamine and } \\
\mathrm{C}_{5} \mathrm{H}_{9} \mathrm{NO}=1 \text {-methyl-2- } \\
\text { pyrrolidinone }\end{array}$ & $\mathrm{C}_{5} \mathrm{H}_{9} \mathrm{NO}$ & [66] \\
\hline$\left[\mathrm{Cu}\left(\mathrm{C}_{12} \mathrm{~N}_{2} \mathrm{H}_{8}\right)_{2}(\mathrm{OAc})\right] \mathbf{5} \mathrm{C}_{4} \mathrm{H}_{9} \mathrm{NO}$ & $\begin{array}{l}\mathrm{C}_{12} \mathrm{~N}_{2} \mathrm{H}_{8}=1,10- \\
\text { phenanthroline }\end{array}$ & $\begin{array}{l}\mathrm{C}_{4} \mathrm{H}_{9} \mathrm{NO}=N, N- \\
\text { dimethyl } \\
\text { acetamide }\end{array}$ & [67] \\
\hline$\left[\mathrm{Mn}\left(\mathrm{C}_{10} \mathrm{H}_{28} \mathrm{~N}_{6}\right)\right] \mathbf{5}_{2}$ & $\begin{array}{l}\mathrm{C}_{10} \mathrm{H}_{28} \mathrm{~N}_{6} \text { is } \\
\text { pentaethylenehexamine }\end{array}$ & & [68] \\
\hline$\left[\mathrm{Ni}(\mathrm{en})_{3}\right] \mathbf{5}_{2} \cdot 2 \mathrm{H}_{2} \mathrm{O}$ & en $=1,2$-ethylenediamine & $2 \mathrm{H}_{2} \mathrm{O}$ & [26] \\
\hline$\left[\mathrm{Ni}(\mathrm{en})_{2}\left(\mathrm{C}_{4} \mathrm{H}_{10} \mathrm{~N}_{2}\right)\right] \mathbf{5}_{2}$ & $\begin{array}{l}\text { en }=1,2 \text {-ethylenediamine } \\
\text { and } \mathrm{C}_{4} \mathrm{H}_{10} \mathrm{~N}_{2}=\text { piperazine }\end{array}$ & & [69] [70] \\
\hline$\left[\mathrm{Ni}(\text { dap })_{3}\right] \mathbf{5}_{2} \cdot \mathrm{H}_{2} \mathrm{O}$ & dap $=$ 1,2-diaminopropane & $\mathrm{H}_{2} \mathrm{O}$ & [63] \\
\hline$\left[\mathrm{Ni}(\text { dien })_{2}\right] \mathbf{5}_{2}$ & dien $=$ diethylenetriamine & & [71] \\
\hline$\left[\mathrm{Zn}(\text { dien })_{2}\right] \mathbf{5}_{2}$ & dien $=$ diethylenetriamine & & [72] \\
\hline$[\mathrm{Zn}(\mathrm{OAc})($ teta $)] \mathbf{5}$ & $\begin{array}{l}\text { teta }= \\
\text { triethylenetetraamine }\end{array}$ & & [73] \\
\hline \multicolumn{4}{|l|}{ Metal cations } \\
\hline $\mathrm{Cs} 5.2 \mathrm{H}_{2} \mathrm{O}$ & & $2 \mathrm{H}_{2} \mathrm{O}$ & [74] \\
\hline $\mathrm{Rb5} .2 \mathrm{H}_{2} \mathrm{O}$ & & $2 \mathrm{H}_{2} \mathrm{O}$ & [31] \\
\hline
\end{tabular}

